\title{
Regenerative medicine for digestive fistulae therapy: benefits, challenges and promises of stem/stromal cells and emergent perspectives via their extracellular vesicles
}

\author{
Anna C Sebbagh ${ }^{\mathrm{a}}$, Boris Rosenbaum ${ }^{\mathrm{b}}$, Guillaume Péré ${ }^{\mathrm{a}, \mathrm{b}, \mathrm{c}}$, Hadrien Alric ${ }^{\mathrm{a}, \mathrm{b}, \mathrm{d}}$, Arthur \\ Berger $^{\mathrm{b}}$, Claire Wilhelm ${ }^{\mathrm{a}}$, Florence Gazeau ${ }^{\mathrm{a}}$, Noëlle Mathieu ${ }^{\mathrm{e}}$, Gabriel

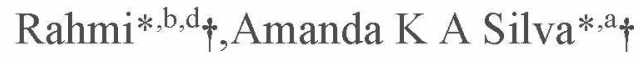

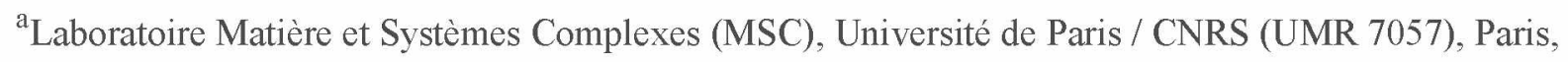
France

${ }^{\mathrm{b}}$ Laboratoire Imagerie de 1'Angiogénèse, Plateforme d'Imagerie du Petit Animal, Inserm UMR970, Paris Cardiovascular Research Center, Paris, France

${ }^{\mathrm{c} D}$ Department of Digestive Surgery, Esogastric bariatric and endocrinal surgery unit, ToulouseRangueil University Hospital, Toulouse, France

${ }^{\mathrm{d}}$ Department of Gastroenterology and Endoscopy, Hôpital Européen Georges Pompidou, Assistance Publique Hôpitaux de Paris, Paris, France

${ }^{\mathrm{e}}$ Human Health Department, SERAMED, LRMED, Institute for Radiological Protection and Nuclear Safety, Fontenay-aux-Roses, France

$\uparrow$ These authors contributed equally to this work

\begin{abstract}
Despite current management strategies, digestive fistulae remain extremely debilitating complications associated with significant morbidity and mortality, generating a need to develop innovative therapies in these indications. A number of clinical trials and experimental studies have thus investigated the potential of stem/stromal cells (SCs) or SC-derived extracellular vesicles (EVs) administration for post-surgical and Crohn's-associated fistulae. This review summarizes the physiopathology and current standards-of-care for digestive fistulae, along with relevant evidence from animal and clinical studies regarding SC or EV treatment for post-surgical digestive fistulae. Additionally, existing preclinical models of fistulizing Crohn's disease and results of SC therapy trials in this indication will be presented. The optimal formulation and administration protocol of SC therapy products for gastrointestinal fistula treatment and the challenges for a widespread use of darvadstrocel (Alofisel) in clinical practice will be discussed. Finally, the potential advantages of EV therapy and the obstacles towards their clinical translation will be introduced.
\end{abstract}

Keywords: Gastrointestinal fistulae, Crohn's disease, stem/stromal cells, post-surgical fistulae, extracellular vesicles

\footnotetext{
* Correspondence: amanda.silva@univ-paris-diderot.fr, gabriel.rahmi@aphp.fr
} 


\section{Introduction}

A fistula corresponds to an abnormal communication between two epithelialized surfaces [1]. Specifically, gastrointestinal fistulae arise as iatrogenic complications following surgery in approximately $75-85 \%$ of the cases $[2,3]$. Crohn's disease represents the main aetiology for primary gastrointestinal fistula occurrence in developed countries [4]. Other potential causes include neoplasia, trauma, infections, exposure to ionizing radiation, foreign bodies, etc [2-6]. Internal gastrointestinal fistulae can develop between any two parts of the gastrointestinal tract (entero-enteric fistulae, gastrojejunocolic fistulae, etc) or between any part of the gastrointestinal tract and another hollow structure (rectovaginal fistulae, colovesical fistulae, aorto-duodenal fistulae, etc) [1,4,7,8]. External gastrointestinal fistulae, or enterocutaneous fistulae, correspond to those fistulae that drain to the skin [1].

Gastrointestinal fistulae are challenging to manage and constitute an extremely debilitating complication for the patient, associated with prolonged hospital stays and dramatically increased morbidity and mortality rates [2,5]. Healing is not always achieved and a significant proportion of
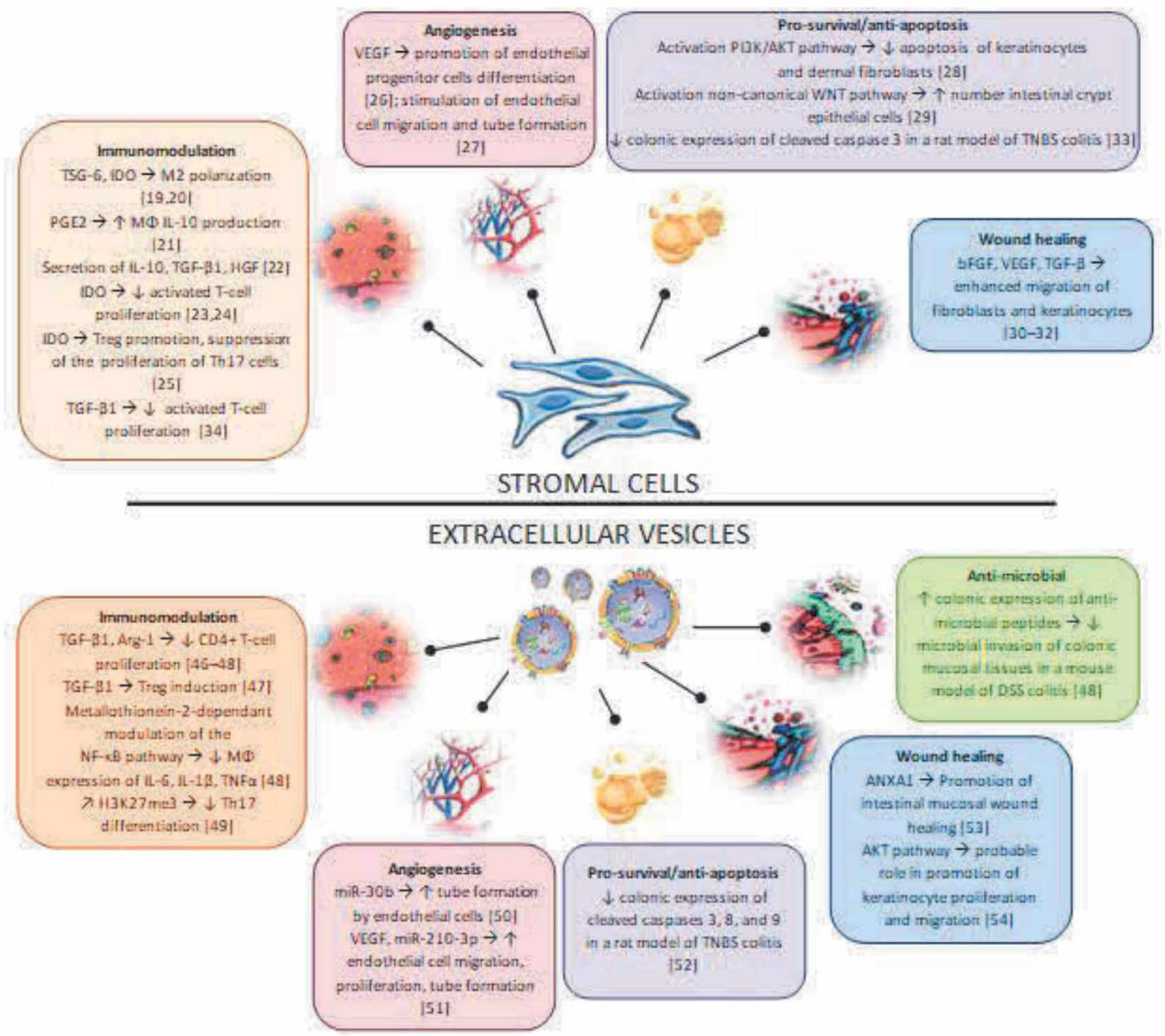

Figure 1: Some of the putative mechanisms of action of stromal cells and extracellular vesicles of interest for digestive fistula therapy. TSG-6: tumor necrosis factor-stimulated gene 6; IDO: indoleamine 2,3-dioxygenase; PGE2: prostaglandin E2; MФ: macrophage; IL-10: interleukin 10; TGF- $\beta$ : transforming growth factor $\boldsymbol{\beta}$; HGF: hepatocyte growth factor; Treg: regulatory T-cells; Th17: T-helper 17; VEGF: vascular endothelial growth factor; PI3K: phosphoinositide 3-kinase; bFGF:

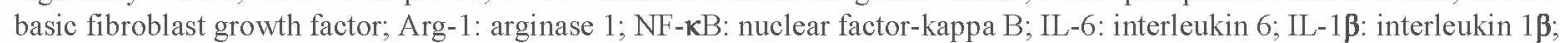
TNF $\alpha$ : tumor necrosis factor $\alpha$; H3K27me3: histone 3 lysine 27 trimethylation; miR-30b: microRNA 30b; miR-210-3p: microRNA 210-3p; TNBS: 2,4,6-trinitrobenzene sulfonic acid; ANXA1: annexin A1; DSS: dextran sulfate sodium

patients will have to live with a permanent diverting stoma [9], with a significant impact on their 
quality of life. Moreover, especially in Crohn's disease, the recurrence of previously healed fistulae constitutes a common occurrence $[10,11]$. These poor outcomes associated with gastrointestinal fistulae have prompted continued experimental and clinical research for the development of innovative treatment approaches, notably based on stem cell therapy, so as to add effective new alternatives to current management algorithms.

Stem cell therapy has brought along tremendous hope in the medical community as a potential solution for the treatment of a wide range of complex pathologies. Due to the ethical and safety issues linked with the use of pluripotent stem cells [12], many clinical studies have focused on the use of adult stem cells, such as stromal cells ( $\mathrm{SCs}$ ), a heterogeneous cell population also known as mesenchymal stem cells. SCs are adult, non-hematopoietic, multipotent cells that can differentiate into several cell types - such as osteoblasts, chondroblasts, adipocytes, tenocytes, etc. They are further characterized by an adherent, spindle-shaped morphology, along with the expression of surface markers such as CD73, CD90 and CD105 and the absence of expression of markers of the hematopoietic lineage (CD45, CD19, CD14, CD11b, CD79 $\alpha$, HLA-DR, etc) [13]. SCs were historically isolated from the bone marrow. Other sources notably include umbilical cord blood, Wharton's jelly, tendons, the synovial membrane, the periosteum, etc. Of particular interest for regenerative medicine, a population of SC-like cells called adipose-derived stromal cells (AdSCs) can easily be harvested at high yields from the adipose tissue through liposuction [14]. Initially, the therapeutic effects of SCs were mostly attributed to their differentiation potential [14], thus providing a replacement for compromised functional cells through homing to the injured tissues. However, the prominent interest of SCs for regenerative medicine has rapidly gone beyond their ability to differentiate into multiple cell types, with the preclinical and clinical demonstration of their propensity to promote endogenous wound healing and angiogenesis, along with their immunomodulatory properties and anti-fibrotic effects (Figure 1, [15-34]). Moreover, the results from several animal studies and clinical trials led to challenge the assumption of a direct contribution of SCs to tissue regeneration. On the one hand, it was shown that only very few SCs would durably engraft at the injury site [29,35]. Indeed, after systemic administration, most of the injected cells become entrapped in the pulmonary capillaries $[29,35,36]$, and the presence of an inflammatory environment at the injury site is highly deleterious to stem cell survival [29]. On the other hand, the therapeutic effect of SCs often seemed to occur in an overly short time frame to be solely attributed to their direct differentiation into functional cells [35]. These preclinical results, along with the observation of equivalent therapeutic effects with SC-conditioned medium, prompted a change of paradigm in stem cell therapy towards mostly paracrine mechanisms of action [37]

Amongst all the potential effectors for these paracrine effects, SC-derived extracellular vesicles (EVs) have gained increasing interest for regenerative medicine in recent years. EVs correspond to a heterogeneous group of subcellular entities that are secreted by cells in a constitutive or induced manner $[38,39]$. They are outlined by a membrane and are usually of a nanometric scale $(40-5000 \mathrm{~nm})$ Several subsets of EVs have been described depending on their biogenesis pathway, like exosomes, which stem from the endosomal network and are released upon fusion of late endosomes with the plasma membrane; microvesicles, which are formed by outward budding and rupture of the plasma membrane; or apoptotic bodies, resulting from cell blebbing during programmed cell death $[38,39]$. However, it is now recommended to favor a classification of EVs based on parameters such as size or biochemical composition, which are technically easier to assess [40]. EVs carry lipids, proteins, mRNAs, miRNAs, and their contents depend both on their parent cells and on their method of production [38,39]. Physiologically, EVs serve as mediators for intercellular communication [38,39]. SC-derived EVs have demonstrated anti-apoptotic properties, along with a propensity to increase cell survival through the activation of the PI3K/Akt pathway, and to promote cell proliferation and wound 
healing [41-43]. They have also demonstrated anti-inflammatory, immunomodulatory and anti-

fibrotic properties (Figure 1, [37,42,44-54]). Their potential for regenerative medicine has thus been shown in preclinical studies for a wide variety of pathologies, including myocardial ischemia/reperfusion injury, acute kidney injury, type 2 diabetes mellitus, liver fibrosis, intervertebral disk degeneration, etc $[41,42,45,55,56]$, and emerging evidence tends to indicate their interest for the treatment of gastrointestinal fistulae [57,58].

This review aims at summarizing current knowledge and discussing the benefits, challenges and promises of SC-based and EV-based therapies for the treatment of fistulae of the digestive system. It will mostly focus on fistulae of post-surgical aetiology, including both gastrointestinal and pancreatic fistulae, and on fistulizing Crohn's disease. The use of SC therapy for perianal fistulae of cryptoglandular origin, already reviewed in details elsewhere $[59,60]$, will be shortly described in the supplementary materials (Supplementary table 1). First, we will present the physiopathology and treatment of post-surgical and Crohn's-associated fistulae, then available evidence supporting their therapy with SCs and EVs will be exposed. Finally, current challenges and perspectives for their clinical translation will be discussed.

\section{Digestive fistulae}

Different types of digestive fistulae and the associated surgical treatment modalities are presented in Figure 2.

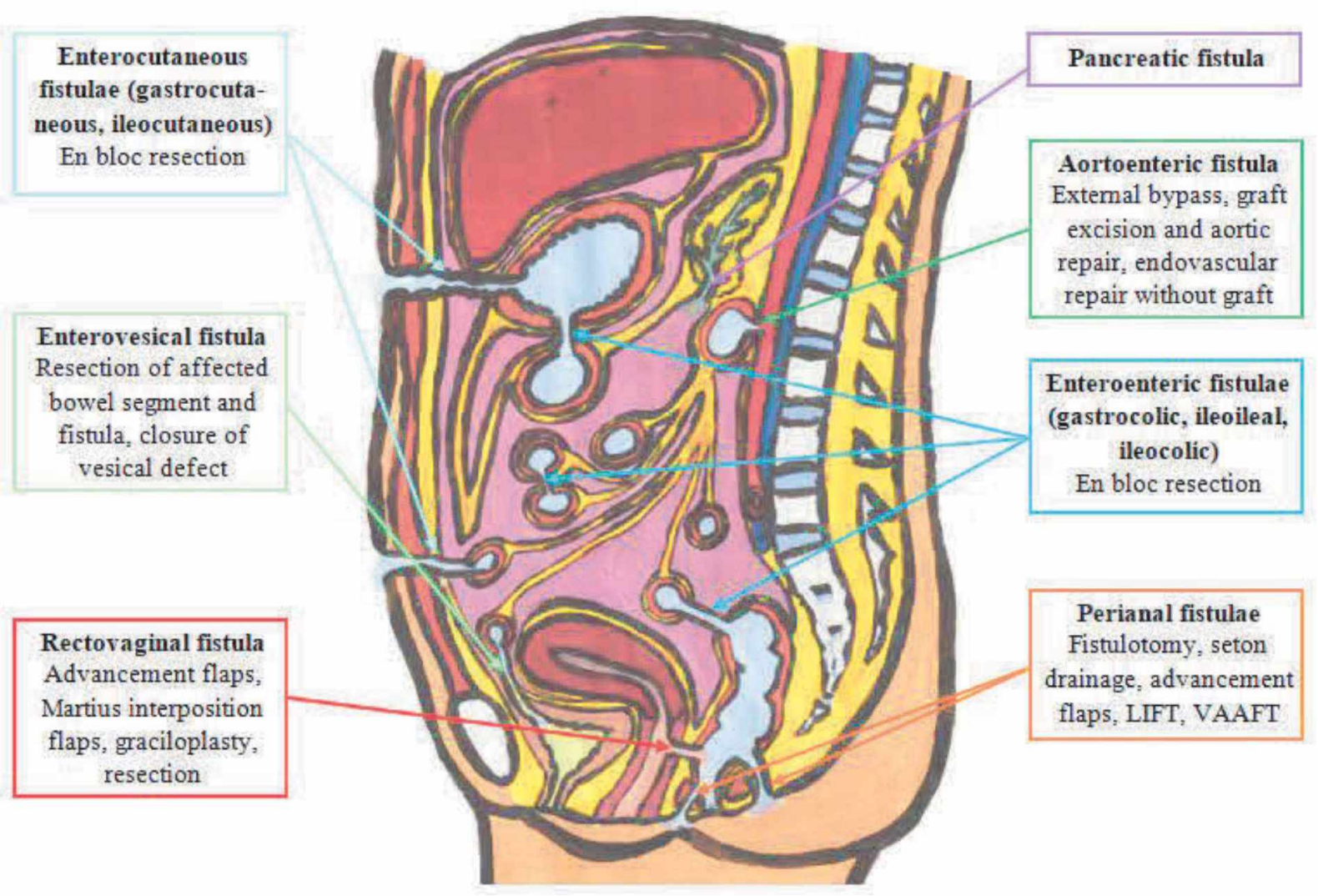

Figure 2 : Digestive fistulae - main strategies for definitive surgical closure. LIFT: Ligation of the intersphincteric fistula tract. VAAFT: Video-assisted anal fistula treatment.

\subsection{Epidemiology and physiopathology}

Gastrointestinal fistulae occur mostly as post-surgical complications (75-85\% of the cases), especially following surgery for cancer, inflammatory bowel diseases and lysis of adhesions $[2,3]$. 
Fistula incidence can vary drastically depending on the procedure $(6.3 \%$ in non-colorectal abdominal surgery including bowel suture or anastomosis [61], 10-11\% following surgery for gastric cancer $[62,63]$, and about $15 \%$ of anastomotic failure following colorectal surgery [64]). Post-surgical fistulae are often linked with anastomotic failure or inadvertent enterotomies, leading to the leakage of luminal contents outside of the gastrointestinal tract [3-5]. Such leakages can cause severe, potentially lethal, infectious complications like abscesses or peritonitis. Progressive extension of an abscess by erosion of neighboring tissues results in the formation of a fistula tract [65]. Inadequate surgical technique (tension on the suture lines, devascularization resulting in local ischemia) and local factors (perianastomotic infection, involvement of diseased segments of the gastrointestinal tract) constitute predisposing factors to anastomotic failure [4]. Additionally, dense adhesions and/or distal obstruction [66,67], emergency surgery without adequate preoperative preparation, along with patient-related factors such as malnutrition or systemic hypotension [4], have been implicated in the physiopathology of post-surgical fistulae. The development of post-surgical fistulae significantly alters the patient's prognosis. Mortality rates ranging from 10 to over $30 \%$ have been reported for enterocutaneous fistulae in recent years [63,68-71], depending on their localization and output. Morbidity and mortality are often linked to malnutrition, fluid and electrolyte imbalances and infectious complications leading to sepsis [2,3]. Moreover, probably owing to these complications and the associated deterioration of the patient's overall condition, post-surgical fistulae incidence in cancer patients may result in their not receiving adjuvant chemotherapy [72], which will further decrease their prognosis. Gastrointestinal fistulae might cause malnutrition or fluid and electrolyte imbalances through several mechanisms [1,2]: internal fistulae bypassing large portions of the digestive tract may result in malabsorption and diarrhea; considerable loss of fluids, electrolytes and nutrients may be observed, especially in the case of high-output fistulae; poor oral intake is common; and finally, patients might be hypercatabolic due to septic complications. Severe haemorrhagic complications may also occur, notably in the case of aorto-enteric fistulae or arterial exposure to pancreatic secretions in the case of post-surgical pancreatic fistulae $[4,73]$.

In 15 to $25 \%$ of the cases, gastrointestinal fistulae will develop spontaneously, notably in the course of Crohn's disease [2,3]. Crohn's disease is a chronic inflammatory bowel disease affecting over 1,000,000 patients in Europe with over 75,000 new cases each year [74]. It is considered a multifactorial pathology, linked with an association of genetic and environmental determinants, alterations of the gut microbiota, an increased intestinal permeability, and a dysregulated immune response, resulting in lesions potentially all along the digestive tract [75-80]. Fistulization constitutes a relatively common complication, affecting up to $35-40 \%$ of Crohn's patients [1]. Penetrating Crohn's disease mainly includes fistulae of the ano-perineal sphere (Figure 3), but also rectovaginal fistulae, entero-enteric fistulae, enterocutaneous fistulae, etc. The pathogenesis of penetrating Crohn's disease is quite complex. Crohn's patients present impaired wound healing mechanisms, notably linked to a decreased migratory potential of colonic lamina propria fibroblasts $[81,82]$. These impaired wound repair mechanisms might trigger an epithelial-to-mesenchymal transition (EMT) in intestinal epithelial cells, initially in an attempt to repair an intestinal lesion $[82,83]$. EMT of intestinal epithelial cells is notably induced by TGF $\beta$ and further increased by pro-inflammatory cytokines such as TNF $\alpha$ or IL- 
13 , resulting in the formation of myofibroblastlike cells called transitional cells $[82,83]$.

Transitional cells then deeply penetrate into the gut mucosa and form a tube-like structure, which might extend to an adjacent organ or the abdominal wall $[82,84]$. This process is further facilitated by extracellular matrix remodeling through increased expression of matrix metalloproteinases such as MMP-3 and MMP$9[82,83]$. The presence of underlying Crohn's disease constitutes a low prognosis factor for spontaneous fistula healing, especially in the case of uncontrolled inflammation [85].

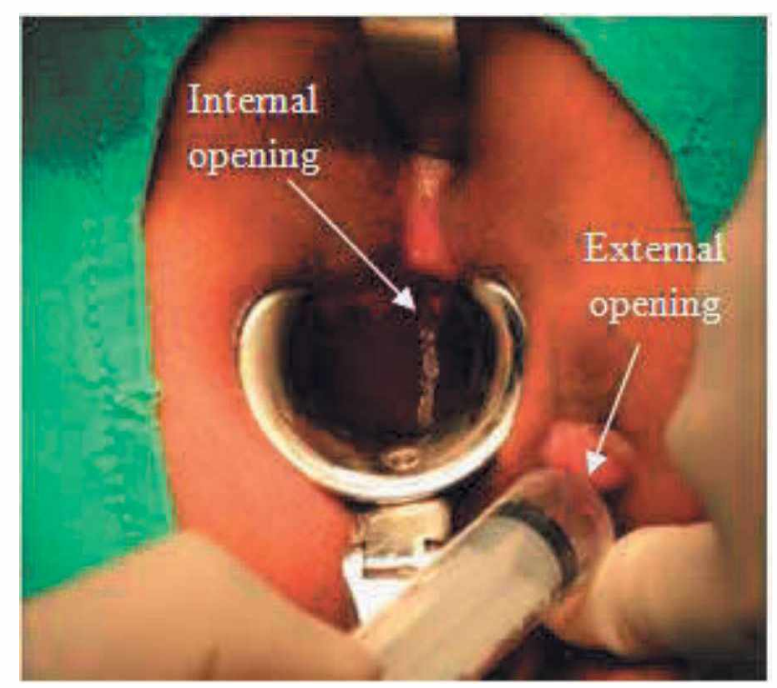

Figure 3: Perianal fistula. The injection of water, saline or dyes through the external opening facilitates the identification of the internal opening. Adapted with permission from Springer, Techniques in Coloproctology "LIF T procedure: a simplified technique for fistula-in-ano" A. Rojanasakul C2009

\subsection{Current management principles}

Gastrointestinal fistulae management is a complex procedure necessitating combined medical, radiological, endoscopic and surgical treatment modalities. The main principles are first to limit the associated complications, and then to reestablish continuity of the gastrointestinal tract. In the acute phase, infection should first be controlled, notably through percutaneous, endoscopic or surgical drainage of the abscesses [2,3]. In the presence of signs of sepsis, broad-spectrum antibiotherapy should be rapidly initiated then adapted to microbiological tests results [3,5]. The patient should then be provided with nutritional support adapted to the anatomical location of the fistula, to the volume and contents of fistula output, and to their overall state $[2,3,5]$

To promote spontaneous fistula healing and reduce morbidity, fistula output should be decreased, and in the case of external fistulae, exposure of the skin to fistula secretions should be avoided to limit local complications, such as pain or infection [3,5]. Despite proper conservative care, spontaneous healing, which usually occurs in 4 to 6 weeks, remains rare (about $20-30 \%$ of the cases for enterocutaneous fistulae [5], depending on fistula localization [71]), with a frequent chronicization of the fistula.

Definitive surgical closure is therefore often necessitated [5]. Only patients with an adequate nutritional status and an absence of sepsis are eligible for definitive surgical closure [3]. These invasive procedures notably include en-bloc resection of the fistula tract and the involved bowel segments with restoration of bowel continuity through anastomosis, and may be associated with severe complications such as fistula recurrence or short bowel syndrome $[3,5,65,66]$.Temporary proximal intestinal diversion may sometimes be required to control fistula output before surgical treatment, and the risk of permanent stoma remains very high [9].

The treatment of primary fistulae arising in the context of Crohn's disease differs due to the presence of inflammation. Recent guidelines promote a combined medical and surgical therapy [86,87], to manage infectious complications, control luminal inflammation and promote fistula closure. Anti-TNFa biotherapies such as infliximab are currently recommended as first-line therapies for the induction and maintenance of remission in complex perianal fistulae in Crohn's disease [86]. However, results from the randomized controlled trial ACCENT II revealed significant rates of failure $(30 \%)$ or loss of response $(42 \%)$ [88] and data on their use in non-perianal fistulae remains limited [1] 
Other biological agents, such as ustekinumab (anti-IL12 and IL23) or vedolizumab (anti-integrin $\alpha_{4} \beta_{7}$ ) are currently under exploration for fistulizing Crohn's disease, however there is still insufficient evidence to recommend their use in this indication [86].

Emerging therapies for persisting fistulae tend to advocate minimally invasive treatments through endoscopic placement of stents, through-the-scope or over-the-scope clips [89], or the use of various sealing agents such as fibrin glue [90], cyanoacrylic glue [91] or the thermoresponsive hydrogel poloxamer 407 [92]. Amongst them, the possibility of stem/stromal cell therapy has received growing attention over the years.

\section{Post-surgical fistulae: a new hope provided by stem/stromal cells}

\subsection{Stem/stromal cells for the treatment of post-surgical fistulae - Evidence from animal studies}

Due to the high morbidity and mortality rates still observed with post-surgical fistulae, preventing their development constitutes a very attractive treatment strategy $[5,73]$.

In this regard, the potential of stem/stromal cells to improve colonic anastomoses healing has been studied in rat models, however a preventive effect of stem cells on the development of anastomotic fistulae could not be found, though the low basal rates of post-surgical fistulae incidence in those models might have biased the results [93].

Some better results were obtained in experimental studies of per-operative local cell sheet placement to prevent post-surgical pancreatic fistulae development [94-96]. Rat models of postsurgical pancreatic fistulae were established by splenic pancreatic duct transection $[94,95]$ or gastric and splenic pancreatic ducts division with distal pancreatectomy and splenectomy [96]. One study investigated sheets formed with 1 million rat myoblasts on thermoresponsive culture plates [94]. Another compared murine AdSC multilayered sheets in the presence or absence of mannose, formed with 0.5 million magnetically-labeled AdSCs in a collagen/Matrigel solution [95]. A third study compared rat AdSC and bone marrow-derived stromal cell (BM-SC) sheets, formed with 1.1 million cells on thermoresponsive culture plates [96]. With cell sheet treatment, less pancreatic leakage was observed in the early post-operative course, as evidenced by intra-abdominal fluid volume [96] and ascitic pancreatic amylase and lipase concentrations [94,95]. It also led to less associated intraabdominal damage [94,95], less inflammatory cell infiltration [94-96], an increased tissue regeneration [96] and better survival at 1 month [94]. A different cell source [96] or the adjunction of mannose [95] did not significantly alter these results. Moreover, a control experiment using collagen sheets without cells enabled to exclude a mere physical effect as the mechanism of action of the cell sheets [95].

Overall, these 3 studies tend to show some beneficial effects of cell sheets for the prevention of post-operative pancreatic fistula development. However, as underlined by Kim et al. [96], the experimental models used in those studies were not completely representative of the clinical situation. Therefore, further studies with a longer follow-up in more clinically relevant, large animal models are needed before an eventual clinical translation.

The potential of stem/stromal cell therapy has also been studied in experimental models of enterocutaneous fistulae, this time as a curative treatment modality [97-100]. These experimental models, due to the absence of underlying pathology, were more representative of fistulae of postsurgical origin. In spite of extensive differences in terms of protocol, all 4 studies evidenced some promising results.

A first study, in a rat model of enterocutaneous fistula established by performing a $5 \mathrm{~mm}$ enterotomy on the caecum and suturing it to the abdominal wall, investigated the local administration of 1 million human AdSCs either through local injection or through their adhesion to the suture material used [97]. At 21 days post-administration, the area of the fistula had decreased considerably 
in both groups treated with cells, especially in the suture group, compared to the control; however this was only evidenced by image analysis of successive photographs of the external opening, therefore these results, though promising, still remain very preliminary. In another study, gastrocutaneous fistulae were created in rabbits by gastrotomy, and, after two hours for leakage formation, the insertion of a tube in the lesion as a drain. 2 weeks later, the drain was removed and autologous stromal vascular fraction (SVF, containing AdSCs) was injected into the fistula tract [98]. At 3 weeks post treatment, examination of the external openings and histological analysis of the fistula tract evidenced patent tracts with draining, inflamed external openings in the untreated control group and nearcomplete healing in the SVF group. However, this study presents a limited precision preventing a fully objective comparison between both groups (for instance, the mean percentage of tract closure is given for each group without any indication on intra-group variability). A more thorough study evaluated the potential of human BM-SC sheets in a murine model of enterocutaneous fistulae created by caecostomy [99]. On the third post-operative day, bi-layered sheets, containing 2 million cells either labeled with both magnetic nanoparticles and a fluorescent dye or unlabeled, were positioned into the fistula orifice. 2 weeks after transplantation, clinical evaluation, MRI, histological analysis and probebased confocal laser endomicroscopy results indicated better healing in both the labeled and unlabeled sheet groups compared to the control with less inflammation and fibrosis, enhanced microvascularisation, a lower fistula surface and a decreased maximal size of the fistulous orifice. The mechanism of action of the sheets was investigated by following the fate of labeled cells post transplantation and analyzing the expression of diverse signaling molecules, suggesting an indirect upregulation of host trophic factors rather than a direct contribution of cells to fistula repair. Such experiments unraveling the fate and mechanism of action of the administered stem cells will be crucial in the long run for clinical translation. A fourth study evaluated the benefits of local injection of allogeneic rat AdSCs (4 million cells) in the perifistular tissues in a similar model of caeco-cutaneous fistula in the rat 4 weeks after fistula creation [100]. The control group was injected with a similar amount of saline instead. One month after treatment, 6 fistulae out of 16 had closed in the AdSC group against 1 out of 16 in the control group $(\mathrm{p}=0.033)$; and no deaths or treatment-related adverse effects were reported in either group. However, these clinical observations were not completed by either radiological or histological analyses of the fistulous tract.

Overall, current evidence from small animal models highlights the potential of the local administration of stromal cells as a curative treatment for enterocutaneous fistulae. However, more experimental studies are warranted in large animal models, with longer follow-up periods, thorough investigation of fistula healing through different modalities, and a more in-depth analysis of the mechanism of action through which cells contribute to fistula healing.

\subsection{Stem/stromal cells for the treatment of post-surgical fistulae - Evidence from clinical trials}

As of today, few clinical trials assessing the potential of stem/stromal cell therapy for the treatment of post-surgical fistulae have been conducted, however, current evidence, though scarce, remains promising.

A first open-label phase I clinical trial investigated the safety and efficacy of autologous adiposederived cells (AdRCs) for post-surgical enterocutaneous fistulae [101]. Autologous AdRCs (similar to SVF, non-expanded mononuclear cells from the adipose tissue containing a heterogeneous cell population with relatively high concentrations of AdSCs) were isolated from gluteal subcutaneous adipose tissue samples using the Celution $(\mathbb{R})$ system. 6 patients with persisting refractory enterocutaneous fistulae secondary to gastrointestinal surgery were included. All patients had underlying inflammatory bowel disease ( 4 cases of ulcerative colitis, including one with a concomitant rectal carcinoid, and 2 cases of Crohn's disease), and had developed enterocutaneous fistulae following total proctocolectomy with ileal pouch-anal anastomosis, or low anterior resection, or 
ileocecal resection (with or without anterior resection). Fistula duration was 5-44 months. Treatment was administered locally, with half of the cells injected in the neighboring tissues (endoscopically and percutaneously), and the other half mixed with fibrin glue and injected into the fistula tract to seal it, before closure of the external opening. The dose ranged from 9.6 to 142 million AdRCs. Fistula closure was defined as the cessation of drainage with no recurrence of an abscess or fistula observed at endoscopy or computed tomography. 5 patients out of 6 achieved fistula closure at 4 weeks, which persisted to the end of the follow-up period ( 24 weeks) associated with ileostomy closure in 4 patients and the possibility to resume oral food intake in 1 . The $6^{\text {th }}$ patient achieved complete reepithelialization only at week 24 and presented a recurrence at 10 months due to pouchitis relapse. No serious adverse effect related to treatment was reported. Adverse effects related to treatment consisted in pain and mild subcutaneous haemorrhage linked to liposuction. Overall, this pilot clinical trial reveals encouraging preliminary results in terms of safety and efficacy of local AdRC therapy in this indication, warranting further investigation to confirm them at a larger scale in randomized, placebocontrolled clinical trials.

Another phase I clinical trial, led by W.A. Faubion at the Mayo Clinic, investigating local AdSC administration via a bioabsorbable fistula plug for post-surgical fistula treatment has recently been completed ( $n^{\circ} \mathrm{NCT} 02807389$ ). These results are yet to be published. Their protocol was based on previous clinical trials investigating AdSC delivery through a fistula plug for the treatment of fistulizing Crohn's disease (perianal and rectovaginal fistulae [102,103]) and cryptoglandular perianal fistulae [104]. 15 patients were to be enrolled. The main inclusion criteria consisted in the presence of a single-tract persisting symptomatic fistula secondary to gastro-esophageal resection, enteric or colonic resection, or bariatric surgeries and refractory to standard therapy (including at least one endoscopic attempt at fistula closure). Patients with inflammatory bowel diseases, with a malignancy or previous irradiation at the location of the fistula, with sepsis, immunosuppressive treatments or chemotherapy were excluded. Other exclusion criteria included non-enterocutaneous, multiple or end fistulae, fistula tract below $2 \mathrm{~cm}$ in length and/or over $1 \mathrm{~cm}$ in diameter, fistula opening into an abdominal wall defect or fistula output over $2 \mathrm{~L}$ per day. The fistula plug, loaded with 20 million AdSCs, was to be placed endoscopically. The follow-up period was scheduled to extend for 18 months. The primary endpoint was to be safety and tolerability, and efficiency was to be evaluated as a secondary endpoint through the number of patients with fistula closure (defined as the cessation of drainage)

\section{Extracellular vesicles for the treatment of post-surgical fistulae}

Though the potential of EVs as a possible alternative to stem/stromal cell therapy has been extensively investigated for a wide array of diseases, to the best of our knowledge, only two studies so far have described their use as a treatment for post-surgical digestive fistulae [57,58]. In the first of them, esophagocutaneous fistulae were induced in otherwise healthy pigs by inserting plastic stents between the oesophagus and the skin [57]. On the $30^{\text {th }}$ post-operative day, the pigs were treated with either allogeneic AdSC-derived EVs $\left(1.3 \times 10^{11} \mathrm{EVs} / \mathrm{mL}\right)$ embedded in the thermoresponsive hydrogel poloxamer 407 or poloxamer 407 alone. The use of this hydrogel, whose sol/gel transition occurs near $20^{\circ} \mathrm{C}$, enables an injection in liquid form to fill homogeneously the potentially irregular fistula tracts and a swift gelation upon administration to retain the EVs within the fistula tract. Clinical, endoscopic, radiological and histological evaluations on the $45^{\text {th }}$ post-operative day evidenced better healing in the gel and gel+EVs groups compared to the untreated control group; with patent fistula tracts and necrosis in all fistulae of the control group ( $\mathrm{n}=6), 3$ completely closed tracts, 1 partially closed tract and 2 thin tracts in the gel group, and 5 fistulae out of 5 demonstrating complete closure in the 
gel+EVs group. Of note, a decrease in inflammatory cell infiltration and in fibrosis along with increased wound healing and angiogenesis were observed in the treatment groups compared to the control, but this was significant only for the gel+EVs group. Overall, this study provided the first in vivo evidence of the interest of local EV administration for the treatment of post-surgical digestive fistulae. A second study in a rat model of post-surgical enterocutaneous fistulae created by caecostomy tended to confirm these results with a decrease in fistula diameter and drainage after administration of $6 \times 10^{11}$ murine $\mathrm{C} 3 \mathrm{H} / 10 \mathrm{~T} 1 / 2$ - derived EVs in poloxamer 407 compared to poloxamer 407 alone or saline [58]. A decrease in fibrosis and inflammation along with an increased angiogenesis could also be evidenced histologically. Moreover, a biodistribution study over 7 days after radiolabeling with $\left[{ }^{89} \mathrm{Zr}\right]$ zirconium evidenced that local EV administration within poloxamer 407 enabled a better retention of EVs at the fistula site than either local injection in saline or intravenous administration [58]. However, further studies are warranted to replicate these promising results with higher numbers of animals and longer follow-up periods. Notably, a more thorough investigation of the mechanism of action of EVs should be performed before any attempts at a potential clinical translation. Additionally, it would be interesting to vary the amount of EVs administered so as to study a potential dose/response relationship, to compare the therapeutic potential of EVs with that of parent cells in this indication, or to further investigate potential links between mode of delivery, EV retention within the fistula tract and therapeutic effect.

\section{Stem/stromal cells and EVs for the treatment of fistulizing Crohn's disease}

\subsection{Preclinical models of fistulizing Crohn's disease for stem/stromal cell therapy applications}

A number of experimental models of digestive fistulae have been established over the years to gain a more thorough understanding of the pathophysiology of fistulizing diseases, explore potential new therapies and unravel the mechanisms of action of the therapies used in clinical settings (Supplementary Table 2). However, most of them are not relevant for the study of Crohn's-related fistulae due to the lack of underlying inflammatory bowel diseases.

A first model of fistulizing Crohn's disease was reported by Rivera-Nieves et al. in 2003 in rodents [105]. Mice of the Samp1/YitFc strain spontaneously develop severe chronic ileitis whose histological features strongly resemble those of Crohn's disease. Less than $5 \%$ of these mice additionally presented perianal involvement, which included the occurrence of ano-cutaneous fistulae in $40 \%$ of the cases. Therefore, though this mouse strain certainly constitutes an interesting model of Crohn's disease, its relevance for the development of new therapies for perianal fistulizing disease is hampered by this limited overall fistula incidence.

Canine anal furunculosis has also been suggested as a relevant model for perianal fistulizing Crohn's disease [106,107], although the cutaneous sinus tracts do not usually communicate with the rectum in this condition, unlike in Crohn's fistula-in-ano [107]. However, owing to the preclusion of systematic autopsy, the financial costs and the logistics involved in trials with companion animals [108], its widespread use for preclinical pharmacological studies for the treatment of fistulizing Crohn's disease might not be feasible.

In 2019, Flacs et al. developed an experimental model of perianal fistulizing Crohn's disease by inserting a surgical thread for 28 days across the anal sphincter of rats with 2,4,6trinitrobenzensulfonic acid (TNBS)-induced chemical colitis [109], with biweekly instillations of TNBS to maintain inflammation. Persistence of the fistulous tract 1 week post thread removal was proven by MRI in all 9 animals, and the radiopathological findings strongly resembled those observed in perianal fistulizing Crohn's disease. The main limitation of this model, besides those classically associated with the TNBS colitis model [110,111], is the lack of study of the persistence of the fistula tract beyond one week post thread removal. Nevertheless, provided these results can be validated in 
further studies, this straightforward fistula induction protocol and these high fistula persistence rates at 1 week render it very interestingfor the investigation of new therapies for Crohn's fistulae.

Finally, a mouse model of enterocutaneous fistula was established in 2019 by the subcutaneous xenotransplantation of fetal human gut in immunodeficient mice, which resulted in spontaneous fistula development between the transplant and the skin in $17 \%$ of the cases, associated with lymphocytic enteritis and histopathological features close to those of fistulizing Crohn's disease [112]. The relatively low fistulization rate and the ethical and practical concerns raised by the use of human fetal gut are the two main drawbacks to the widespread use of this model. However, it remains the only preclinical model of enterocutaneous Crohn's-associated fistulae described to this day.

To the best of our knowledge, only one study investigated the potential of stem/stromal cell therapy in an animal model of fistulizing Crohn's disease [106]. This open-label, uncontrolled, singlecenter clinical trial included 6 dogs with canine anal furunculosis resistant to standard therapy (cyclosporine). Its main endpoints were the number and depth of fistulae at 6 months post stem/stromal cell therapy and the average dose of cyclosporine necessary to keep the dogs in remission. The dogs were treated with a single local injection of 20 million human embryonic stem cells (hESC)-derived mesenchymal stem/strom cells and fibrin glue. No adverse event was reported except one mild perianal erythema, and no open fistula or ulcer was observed in any of the dogs at 3 months post treatment. Two recurrences were reported at 6 months of follow-up and the mean dose of cyclosporine received by the dogs did not decrease significantly. Overall, this study demonstrated the safety and efficiency of the mentioned approach as an add-on therapy to immunosuppressive drugs for the treatment of perianal fistulizing Crohn's disease in a large animal model. Its main limitations reside in the low number of animals included, the lack of a control group, and the use of SCs derived in vitro from $\mathrm{hESC}$ which might hamper any eventual clinical translation.

\subsection{Stem/stromal cell therapy for the treatment of fistulizing Crohn's disease-Evidence from clinical trials}

Since the first case report in 2003 showing the potential of local autologous AdSCs injection for the repair of recurrent Crohn's-related rectovaginal fistula [113], a number of clinical studies have investigated the safety and efficacy of stem cell therapy in fistulizing Crohn's disease (Table 1, $[102,103,114-136])$. Notably, in 2009, a multicenter, open-label, controlled phase II clinical trial on 49 patients with perianal fistulae either Crohn's-related $(n=14)$ or of cryptoglandular origin $(n=35)$ investigated the potential of autologous AdSCs as an add-on therapy to fibrin glue and demonstrated a better healing in the AdSC group ( $71 \%$ in the Crohn's disease subset) than in the control group ( $14 \%$ in the Crohn's disease subset) 8 weeks after treatment, with a recurrence rate of only $17.6 \%$ at one year [115]. An uncontrolled multicenter phase II study from another group confirmed those encouraging results in 2013 with complete healing observed in 28 patients out of 42 (intention-to-treat analysis, $66.7 \%$ ) at 8 weeks [122] with no recurrence at 2 years in $83.3 \%$ of the cases [124]. Other trials explored the local injection of autologous AdSCs in conjunction with serum [136] or plateletrich plasma [131,132] instead of fibrin glue (Table 1). Interestingly, the combination of cell administration with another sphincter-preserving technique for Crohn's-associated fistula repair has also been studied: indeed, Dietz et al. and Lightner et al. reported the use of autologous AdSC-coated fistula plugs in phase I clinical trials, for the repair of perianal and rectovaginal fistulizing Crohn's disease (Table 1, [102,103]).

The use of autologous SVF or AdRCs, both obtained from adipose tissue without the need for cell expansion, and/or of autologous adipose tissue injection for fistulizing Crohn's disease has also been described [116,129,133-135,137-139].

In 2011, a pilot phase I/II clinical trial of multiple BM-SC injections for the treatment of perianal and enterocutaneous Crohn's-related fistulae on 10 patients evidenced complete healing at 1 year in 7 
patients and a decrease of $>50 \%$ of fistula drainage in 3 [118]. Allogeneic BM-SCs injections have also been investigated in refractory perianal fistulizing Crohn's disease in a double-blind, placebocontrolled, dose-escalating clinical trial [126], and were found to induce a significantly better healing at week 6 at a dose of 30 million cells compared to placebo (though the low numbers of patients included impeded the generalization of this difference to subsequent endpoints).

Two phase I/IIa clinical trials have been conducted on patients with perianal [121] or rectovaginal [128] fistulizing Crohn's disease to study the safety and efficacy of allogeneic AdSCs local injection without fibrin glue adjunction. For perianal fistulae, at 24 weeks post injection, a total of 9 patients (56.3\% of the full analysis population) demonstrated closure of the external openings with combined remission - defined as the complete re-epithelialisation of external orifices, the absence of fistula drainage, either spontaneous or upon compression, and the absence of collections above $2 \mathrm{~cm}$ communicating with the treated fistula tract at MRI - found in 6 patients $(30 \%$ of the full analysis population) [121]. For rectovaginal fistulae, the final efficacy rate was of $60 \%$ (3 patients healed out of 5 at 52 weeks of follow-up), however the reliability of those results can be questioned since half of the included patients dropped out of the study before completing the follow-up period due to a flare-up of luminal disease and/or the need for biological medication [128]. A pilot, dose-escalation trial from another group in 2016 investigated the safety and efficacy of allogeneic AdSCs local injection with fibrin glue for perianal fistulizing Crohn's disease. However, the limited number of patients included in each group precluded them from drawing any firm conclusion on the effectiveness of the 2 different concentrations of cells they tested [127].

The first results from the pivotal ADMIRE-CD trial ( ${ }^{\circ}$ NCT01541579), a large, phase III, randomised, double-blind, placebo-controlled, multicenter ( 49 different centers in 8 countries) clinical trial evaluating the potential of allogeneic AdSCs for the treatment of refractory complex Crohn'sassociated perianal fistula were published in 2016 [130]. 212 patients were included, and received a single local injection of 120 million allogeneic $\operatorname{AdSCs}(n=107)$ or an equivalent volume of saline $(24 \mathrm{~mL}, \mathrm{n}=105)$. The primary endpoint of combined remission at week 24 was achieved in $50 \%$ ( 53 out of 107 patients) in the AdSC group versus 34\% of the control group ( 36 out of 105 patients, $p=0.024$ ) in the intention-to-treat analysis. Higher clinical remission rates (53\% versus $41 \%$ ) and clinical response rates ( $66 \%$ versus 53\%) were observed by week 24 in the AdSC group than in the control, however, the difference was not significant. 131 patients from the phase III trial completed a long-term follow-up study (70 in the treatment group and 61 in the placebo group). This study evidenced a lower recurrence rate in the AdSC group than in the control group at 52 weeks of follow-up [140]. These positive efficacy results for Crohn's-associated fistulae have mainly been attributed to the immunomodulatory properties of SCs, and notably to indoleamine 2,3-dioxygenase-dependant regulation of T-cell activity[141,142].

Most studies have reported a good safety profile of local stem/stromal cells administration for the treatment of fistulizing Crohn's disease (Table 1,[102,103,114-136]). In particular, the ADMIRE-CD trial reported treatment-related adverse events in 18 out of 103 patients included in the safety analysis in the AdSC group (17\%) versus 30 out of 102 in the control group (29\%), including 5 cases of serious treatment-related adverse events in the AdSC group against 7 in the control, by week 24 [130]. After 52 weeks of follow-up, a total of 21 treatment-related adverse effects had been described out of 103 patients (20.4\%) in the AdSC group versus 27 out of 102 (26.5\%) in the control, including 7 cases of serious treatment-related adverse events in each group [140]. One of the greatest concerns with stem/stromal cell therapy is neoplasia development. Biopsies taken from the injection area of 5 patients included in a phase II clinical trial of autologous AdSC and fibrin glue injection for the treatment of complex perianal fistulae [115] showed no evidence of neoplastic tissues up to 2 years after treatment [143], and similarly, no signs of cytologic transformation were observed in biopsies taken at 7 months and 1 year from treatment with autologous AdSCs of, respectively, an 
enterocutaneous fistula and a rectovaginal fistula in the initial phase I trial of 2005 [114]. However, following allogeneic BM-SCs injections for the treatment of refractory perianal fistulizing Crohn's disease, 2 cases of neoplasia were reported: a cecal adenocarcinoma with peritoneal carcinomatosis $>15$ months after the intervention [126] and a rectal Epstein-Barr virus-associated B-cell lymphoproliferative disease 4 years after the intervention [144]. In the first case, a family predisposition was suggested while for the rectal lymphoproliferative disease, it was imputed to Crohn's disease and prolonged immunosuppressive treatments without totally excluding a potential contribution of allogeneic BM-SC injection. Recently, a case series gave some first encouraging insights on the safety profile of SC therapy in terms of fertility and pregnancies [145]

Several systematic literature reviews and meta-analyses in the past 3 years underlined the acceptable safety profile of SC therapy for perianal fistulizing Crohn's disease [146-149]. For instance, a meta-analysis from 3 controlled trials by Lightner et al. reported an absence of significant increase of either adverse events $(\mathrm{OR}=1.07,95 \%$ confidence interval $[0.61 ; 1.89], \mathrm{p}=0.81)$ or serious adverse events $(\mathrm{OR}=0.53,95 \%$ confidence interval $[0.28 ; 0.98] ; \mathrm{p}=0.04)$ after treatment with $\mathrm{SCs}$ [148].

Those positive results in terms of efficacy and security led to the market approval by the European Medicines Agency of expanded allogeneic AdSCs for the treatment of refractory complex Crohn's-associated perianal fistulae in 2018 (market authorization $n^{\circ} \mathrm{EU} / 1 / 17 / 1261 / 001$ ).

\subsection{Extracellular vesicles therapy for fistulizing Crohn's disease - A future direction?}

Evidence from small animal models tends to indicate a potentially beneficial effect of systemic, intra-peritoneal or local stem cells-derived EVs administration for luminal Crohn's disease [150-152] Thus, in view of emerging experimental data on the use of EVs for post-surgical gastrointestinal fistula treatment [57,58], we consider that EV therapy for perianal and non-perianal fistulizing Crohn's disease could constitute an interesting future preclinical research axis.

\section{Limits, challenges and perspectives for clinical translation}

\subsection{Defining the optimal cell source, formulation and administration protocol-An ongoing challenge}

As of today, the question of the optimal formulation and administration protocol for stem/stromal cell therapy products for post-surgical and/or Crohn's-associated digestive fistula treatment remains to be solved. Indeed, though clinical trials have investigated a variety of potential cell sources (adipose-derived versus bone marrow-derived, autologous versus allogeneic, with or without expansion, etc), no controlled trial has formally compared them with one another to investigate potential differences in terms of safety and/or efficacy. In the absence of such evidence, other considerations, such as availability, number and cost of procedures, should be taken into account for clinical studies or compassionate use programs. AdSCs can usually be obtained at high yields through liposuction [14]; however, this might not be feasible in some patients with insufficient levels of adipose tissue. The procedure to

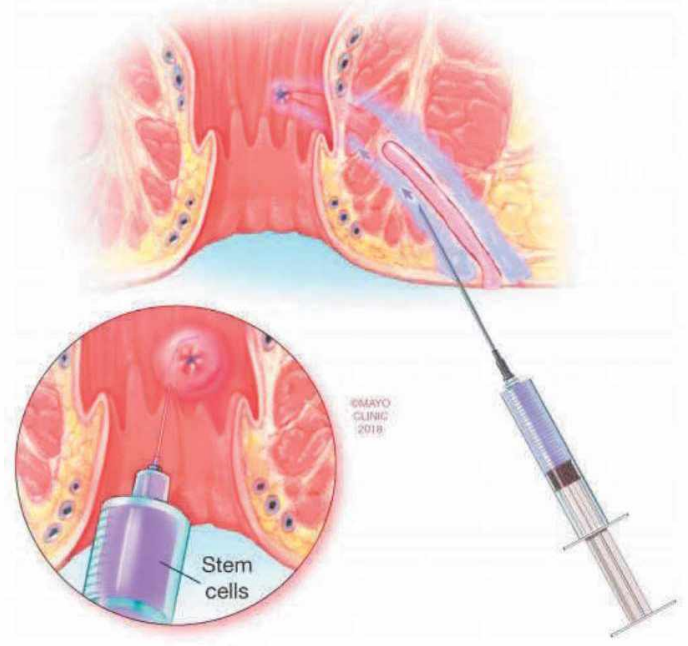

Figure 4: Stem cell application to the internal orifice and fistula tract walls according to standardized protocols. Reprinted with permission from Springer, [153] C2018 harvest BM-SCs, requiring bone marrow aspiration, is classically more invasive [14]. While autologous stem/stromal cells are usually considered safer, results from clinical trials of allogeneic 
ones administrated in perianal fistulizing Crohn's disease demonstrated an acceptable safety profile $[121,126-128,130,140]$. Although some patients developed donor-specific antibodies directed against HLA-I, it was not correlated with therapeutic efficacy [153]. The use of an allogeneic cell source might therefore present several advantages, such as immediate, off-the-shelf availability, avoiding potential age-related or disease-related effects on stem/stromal cells' therapeutic potential, and limiting the number of interventions performed on the patient $[121,126]$. The use of autologous SVF/AdRCs avoids the need for cumbersome, expensive expansion procedures, while permitting reimplantation in the same day, thus limiting the therapeutic delay observed with expanded autologous cells. Moreover, their isolation can be performed in completely closed systems, which will further decrease the risk of sample contamination [134,135,154].

The question of the best administration protocol to maximize therapeutic efficacy while limiting complications and invasiveness constitutes yet another fundamental consideration. Of note, all trials so far have focused on a local administration route for fistula treatment. Indeed, a local administration would seem more relevant in this indication, by limiting off-target effects [155] and enabling the delivery of larger numbers of cells without additional risks of thrombus formation and pulmonary embolism, as sometimes observed after systemic high dose cell treatment $[36,156]$. Several clinical trials have investigated a concomitant use of tissue sealing agents such as fibrin glue. Fibrin glue consists in a solution of human fibrinogen, which will form a clot upon adjunction of thrombin and calcium chloride [157]. It has shown a good safety profile but a limited efficacy as a stand-alone treatment for gastrointestinal fistulae $[3,73,87,158]$. In stem/stromal cell therapy trials, both its use solely as a fistula sealing agent after local cell injection in the perifistular tissues $[114,115,120]$ or as a scaffold to retain part of the cells within the fistula tract $[101,116,122,124,127]$ have been described. However, the added benefits of these approaches to stem/stromal cell therapy alone are yet to be investigated. The administration of AdSC-coated fistula plugs has been described for several different fistula types to permit sustained local retention of high concentrations of cells [102-104]. Though the theoretic rationale behind this approach is certainly attractive, caution is advised in regard of the limited efficacy results reported with fistula plug placement as a treatment for gastrointestinal fistulae $[87,158]$, mostly imputable to early plug extrusion. Of note, this adverse effect, which would lead to a complete loss of all cells administered in this manner prior to fistula healing, has already been reported in the early phase trials of AdSC-coated fistula plugs $[103,104]$. The question of the benefits of multiple administrations and their intervals, which would seem relevant due to the chronicity of gastrointestinal fistulae, has already been raised $[115,118,119,121,122,124,125,128]$ but never properly studied. However, in view of the costs linked with cell therapy and the demonstration of long-term efficacy in the ADMIRE-CD phase 3 randomized controlled trial after a single dose $[130,140]$, it would seem more relevant to consider a repeat administration only in case of a failure of the first one, as was done in the aforementioned trials. In spite of the variety of administration protocols described in clinical trials, adequate prior seton drainage $[102,103,115,119,126,130$ 132,134-136,140], thorough tract curettage and irrigation [101-103,114-116,118-122,124-128,130132,134-136,140], and internal opening closure through sutures and/or an advancement flap $[114,115,119-122,124,126-128,130-132,134-136,140]$ constitute commonly accepted preliminary steps, to, respectively, control sepsis, destroy the granulation tissues or neo-epithelialized tissues lining the fistula tract, and prevent the passage of gastrointestinal luminal contents through the tracts. In the case of perianal fistulizing Crohn's disease, some efforts have been made towards more standardized administration protocols $[155,159]$. Both articles stressed the importance of the aforementioned steps, along with the necessity to thoroughly map and identify the fistula tract and openings prior to treatment for an optimal administration. A precise injection protocol was advocated, with injection of half of the cells around the closed internal orifices and of the other half in the perifistular tissues along the fistula walls (Figure 4). On the other hand, injection of the cells directly within the fistula lumen 
was strongly discouraged in both articles since it would result in their being washed out of the tract. Other important considerations notably included favoring preoperative antibiotherapies, anesthesia techniques and antiseptic agents that will not affect the viability and therapeutic potential of the cell therapy product [155]. A more widespread use of such standardized protocols, validated in clinical trials, would enable an easier comparison of efficacy results between subsequent studies. They may also constitute the first golden standards to serve as a reference for studies aiming at optimizing the administration strategy. 


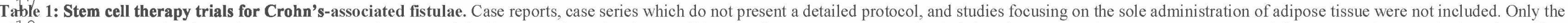

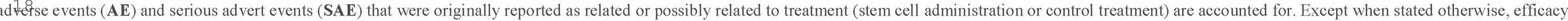

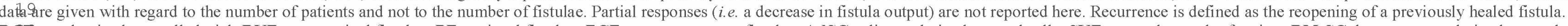

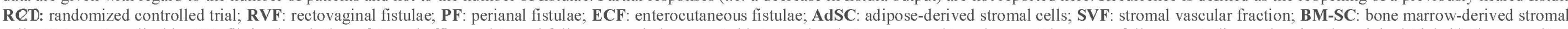

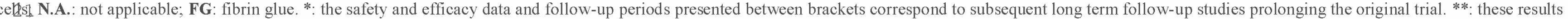
corespond to the whole study population, which also included PF of cryptoglandular origin. $* * \%$ : Half of the patients were excluded during the follow-up period due to severe luminal disease flare-up.

\begin{tabular}{|c|c|c|c|c|c|c|c|c|c|c|c|}
\hline $\begin{array}{l}24 \text { Study } \\
25\end{array}$ & Fistulae & Treatment & Source & Administration & Dose of cells & $\begin{array}{l}\text { Treatment- } \\
\text { related } \mathrm{AE}\end{array}$ & $\begin{array}{l}\text { Treatment- } \\
\text { related SAE }\end{array}$ & $\begin{array}{l}\text { Complete } \\
\text { healings }\end{array}$ & Recurrences & Follow-up & Reference(s) \\
\hline $\begin{array}{l}2 \text { Phase I } \\
27\end{array}$ & RVF/PF/ECF & $\operatorname{AdSC}(n=4)$ & Autologous & Local $\pm \mathrm{FG}(1 \times)$ & $3-30 \times 10^{6}$ & None & None & $\begin{array}{l}75 \% \text { of the } \\
\text { fistulae }\end{array}$ & N.A. & $12-30$ months & [114] \\
\hline \multirow{2}{*}{$\begin{array}{l}28 \\
28 \text { hiase II* } \\
30\end{array}$} & \multirow{2}{*}{$\mathrm{PF}$} & $\operatorname{AdSC}(n=7)$ & Autologous & \multirow{2}{*}{ Local + FG $(1-2 \times)$} & $2 \times 10^{7} \pm 4 \times 10^{7}$ & None & None & 5 out of 7 & $\begin{array}{c}17.6 \% \text { *** }(5 \text { out } \\
\text { of } 12 * *)\end{array}$ & \multirow{2}{*}{$\begin{array}{c}1 \text { year (approx. } 40 \\
\text { months) }\end{array}$} & \multirow{2}{*}[115,119]{} \\
\hline & & Control $(n=7)$ & N.A. & & N.A. & $6^{* * *}$ & 1 & 1 out of 7 & $0\left(1\right.$ out of $\left.3^{* *}\right)$ & & \\
\hline \multirow{2}{*}{$\begin{array}{l}31 \\
32 \text { case } \\
32 \text { series }\end{array}$} & \multirow{2}{*}{$\mathrm{ECF}$} & $\operatorname{AdSC}(n=2)$ & \multirow{2}{*}{ Autologous } & \multirow{2}{*}{ Local $+\mathrm{FG}(1 \times)$} & $3.5-30 \times 10^{6}$ & \multirow{2}{*}{ None } & \multirow{2}{*}{ None } & $75 \%$ & 0 & \multirow{2}{*}{1 year } & \multirow{2}{*}{ [116] } \\
\hline & & $\operatorname{SVF}(n=4)$ & & & $5.5-176 \times 10^{6}$ & & & $25 \%$ & 0 & & \\
\hline Bhase $I / I^{*}$ & $\mathrm{PF} / \mathrm{ECF}$ & BM-SC $(n=10)$ & Autologous & Local $(2-5 \times)$ & $1.5-3 \times 10^{7}$ & None (none) & None (none) & 7 out of 10 & $\begin{array}{c}0 \text { (63\% after } 2 \\
\text { years })\end{array}$ & 1 year ( 5 years $)$ & {$[118,125]$} \\
\hline Phase I & $\mathrm{PF}$ & $\operatorname{AdSC}(n=10)$ & Autologous & Local + FG $(1 \times)$ & $1-4 \times 10^{7} / \mathrm{mL}$ & None & None & 3 out of 10 & 0 & 8 weeks \pm 6 months & {$[120]$} \\
\hline ए̆hase I/IIa & $\mathrm{PF}$ & $\operatorname{AdSC}(n=24)$ & Allogeneic & Local $(1-2 \times)$ & $2 \times 10^{7} \pm 4 \times 10^{7}$ & 5 & 2 & 9 out of 24 & N.A. & 24 weeks & [121] \\
\hline 38 & PF & $\operatorname{AdSC}(n=42)$ & Autologous & Local + FG $(1-2 \times)$ & $\begin{array}{c}3-6 \times 10^{7} / \mathrm{cm} \\
\text { fistula length } \pm \\
1.5 \times \text { as much }\end{array}$ & None (none) & None (none) & 28 out of 42 & $\begin{array}{c}3 \text { out of } 26(4 \\
\text { out of } 24)\end{array}$ & $\begin{array}{c}8 \text { weeks up to a year ( } 2 \\
\text { years) }\end{array}$ & {$[122,124]$} \\
\hline \multirow{4}{*}{$\begin{array}{l}41 \\
42 \mathrm{RCT} \\
43 \\
44\end{array}$} & \multirow{4}{*}{ PF } & \multirow{3}{*}{ BM-SC $(n=15)$} & \multirow{4}{*}{ Allogeneic } & \multirow{4}{*}{ Local $(1 \times)$} & $1 \times 10^{7}$ & None & None & 6 PF out of 9 & 0 & \multirow{4}{*}{24 weeks } & \multirow{4}{*}{ [126] } \\
\hline & & & & & $3 \times 10^{7}$ & None & None & 6 PF out of 7 & 0 & & \\
\hline & & & & & $9 \times 10^{7}$ & None & None & 2 PF out of 7 & 0 & & \\
\hline & & Control $(\mathrm{n}=6)$ & & & N.A. & None & None & 3 PF out of 9 & 0 & & \\
\hline${ }_{45}$ Pilot & $\mathrm{PF}$ & $\operatorname{AdSC}(n=6)$ & Allogeneic & Local + FG $(1 \times)$ & $1-3 \times 10^{7} / \mathrm{mL}$ & None & None & 3 out of 6 & 0 & 8 months & {$[127]$} \\
\hline \multirow{2}{*}{$\begin{array}{l}4 \text { Fhase } 3 \\
47 \text { RCT* }^{*} \\
48\end{array}$} & \multirow{2}{*}{$\mathrm{PF}$} & $\operatorname{AdSC}(n=107)$ & Allogeneic & \multirow{2}{*}{ Local $(1 \times)$} & $1.2 \times 10^{8}$ & $18(21)$ & $5(7)$ & 53 out of 107 & $0(13 / 52)$ & \multirow{2}{*}{24 weeks ( 52 weeks) } & \multirow{2}{*}[130,140]{} \\
\hline & & Control $(\mathrm{n}=105)$ & N.A. & & N.A. & $30(27)$ & $7(7)$ & 36 out of 105 & $0(15 / 34)$ & & \\
\hline Prase I/IIa & RVF & $\operatorname{AdSC}(n=10)$ & Allogeneic & Local $(1-2 x)$ & $2 \times 10^{7} \pm 4 \times 10^{7}$ & None & None & 3 out of $5^{* * * *}$ & N.A.*** & 52 weeks & {$[128]$} \\
\hline $\begin{array}{l}5 \text { Phase I } \\
52\end{array}$ & $\mathrm{PF}$ & $\operatorname{AdSC}(\mathrm{n}=12)$ & Autologous & $\begin{array}{c}\text { Local on a fistula } \\
\text { plug }(1 \times)\end{array}$ & $2 \times 10^{7}$ & None & None & 10 out of 12 & 0 & 6 months & {$[102]$} \\
\hline 53Pilot & $\begin{array}{l}\text { PF/pouch- } \\
\text { vaginal }\end{array}$ & $\operatorname{AdSC}(n=9)$ & Autologous & $\begin{array}{c}\text { Local + platelet-rich } \\
\text { plasma }(1 \times)\end{array}$ & $1-2 \times 10^{8}$ & None & None & $\begin{array}{l}10 \text { fistulae out } \\
\text { of } 11\end{array}$ & 0 & 21-37 months & {$[131,132]$} \\
\hline 5 Bhase I & $\mathrm{PF}$ & $\operatorname{SVF}(n=10)$ & Autologous & $\begin{array}{l}\text { Local }+ \text { adipose } \\
\text { tissue }(1 \times)\end{array}$ & $1.09-4.78 \times 10^{7}$ & 5 & 1 & 6 out of 10 & 0 & 48 weeks & {$[134,135]$} \\
\hline $\begin{array}{l}56 \\
5 \text { Phase I }\end{array}$ & RVF & $\operatorname{AdSC}(n=5)$ & Autologous & $\begin{array}{c}\text { Local on a fistula } \\
\text { plug }(1 \times)\end{array}$ & $3.5 \times 10^{7}$ & None & None & 0 out of 5 & 0 & 6 months & [103] \\
\hline \multirow{2}{*}{$\begin{array}{l}58 \\
59 \\
60 \\
61 \\
61\end{array}$} & \multirow{2}{*}{$\mathrm{PF}$} & $\operatorname{AdSC}(n=11)$ & Autologous & Local $+\operatorname{serum}(1 \times)$ & $\begin{array}{c}5-10 \times 10^{6} / \mathrm{cm} \\
\text { length }\end{array}$ & None & None & 10 out of 11 & 3 out of 10 & \multirow{2}{*}{1 year } & \multirow{2}{*}[136]{} \\
\hline & & Control $(n=11)$ & N.A. & N.A. & N.A. & 11 & None & 6 out of 11 & 0 & & \\
\hline
\end{tabular}




\subsection{Towards a more widespread use - Darvadstrocel and stem/stromal cell therapy for fistula treatment} in clinical reality

To this day, allogeneic AdSC administration as described in the ADMIRE-CD phase III randomized controlled trial $[130,140]$ constitutes the only stem/stromal cell therapy product to have received marketing authorization for gastrointestinal fistulae treatment, as a second line treatment for complex Crohn's-associated perianal fistulae refractory to conventional therapeutic agents and/or biotherapies, under the designation "darvadstrocel" (Alofisel). This relatively restrictive indication constitutes one of the major obstacles towards a more widespread use of darvadstrocel and stems directly from the very specific patient populations enrolled in the ADMIRE-CD trial. Indeed, this trial, like most clinical studies so far, has solely focused on perianal fistulizing Crohn's disease, thus there is not enough clinical evidence yet to recommend the use of this cell therapy for other types of gastrointestinal fistulae outside of clinical studies or compassionate use programs. Moreover, no results have been published to this date in the paediatric population, thus the use of darvadstrocel is currently only indicated for adult patients. Additionally, like most innovative therapies involving cells, darvadstrocel remains very expensive. The reported price for a single dose containing 120 million cells reaches $54,000 €$. Thus, the feasibility of routine use in clinical practice will depend on the possibility of reimbursement and funding, which may not be approved in some countries.

For instance, while the French National Autority for Health has considered darvadstrocel sufficiently beneficial to be eligible for reimbursement by the Social Security, the National Institute for Health and Care Excellence has not given a positive recommendation for funding in the United Kingdom. The medical community nevertheless seems rather favorable to the possibility of allogeneic AdSC injections in this indication. It was indeed already described as a potentially safe and efficient alternative in the most recent guidelines by the European Crohn's and Colitis Organization, although the need for longer term follow-up studies has been emphasized [87]. In this regard, several clinical trials have been launched to answer remaining issues: a multicenter single group open-label trial of single-dose darvadstrocel injection in adult patients with complex refractory perianal fistulizing Crohn's disease is currently being conducted in Japan with a follow-up of safety extending over 3 years (trial ${ }^{\circ}$ NCT03706456). A second phase III randomized controlled trial is currently recruiting to confirm the safety and efficacy data of darvadstrocel at a wider scale (trial n ${ }^{\circ} \mathrm{NCT} 03279081$ ). Finally, an open-label phase 4 study is planned to investigate the long-term safety of repeated administration of darvadstrocel (trial $\mathrm{n}^{\circ} \mathrm{NCT} 04118088$ ).

\subsection{EVs for fistula treatment-a promising research axis despite ongoing translational hurdles}

Beyond their therapeutic potential and the emerging preclinical evidence of their efficacy for fistula treatment, EVs present several advantages which justify ongoing research in spite of the drastically more advanced results already obtained with stem/stromal cell therapy. First and foremost, as a cell-free therapeutic modality, EVs could alleviate most of the remaining safety concerns associated with cells, such as the risks of proliferation and inadequate differentiation; while offering an easier storage and limiting the complex handling issues linked with viable stem cell therapy products $[57,160,161]$. Additionally, EVs can be loaded with drugs, nanoparticles or other agents for controlled drug delivery or imaging purpose [38]. Specifically, in the field of fistula therapy, it could be envisioned to load EVs with anti-bacterial agents to help control sepsis or with immunomodulators in the case of fistulizing Crohn's disease. Of note, their structure comprises a bilayered phospholipidic membrane, allowing local drug delivery through possible fusion with the cell membrane, and protecting their contents from potentially aggressive extracellular environments [38] - here, a fistula tract exposed to gastrointestinal secretions containing enzymes, feces, etc. Moreover, they are produced physiologically and, as such, are less likely to be immunogenic than artificial vectors [38]. In this regard, stem/stromal cell-derived EVs may present an immune-privileged status potentially compatible with their use in allogeneic settings, thus providing off-the-shelf availability which would tremendously facilitate any eventual clinical translation [57]. However, several technical challenges still remain to be overcome before their use in clinical trials (not to mention routine clinical practice) can be envisioned. On the one hand, most 
EV production methods, like parental cell culture in hollow-fiber bioreactors, or under serum starvation, remain very time-consuming, and do not permit to obtain high yields of EVs [38]. Though emerging methods based on the use of physical triggers such as shear stress have drastically improved the yields [38], exposing cells to intense physical stresses might alter their viability and integrity, with a potential impact on the quality of produced EVs, which should therefore properly be characterized. The development of optimized production processes, to obtain high yields of EVs, implementable at a wide scale and compatible with the good manufacturing practices, therefore constitutes a necessary first step to launch wide scale preclinical studies or clinical trials. The same considerations should apply to subsequent isolation steps (which classically include ultracentrifugation, tangential flow filtration, and/or chromatography as of today) [161], while keeping in mind that many different factors throughout the fabrication process - from the choice of parental cells to the final isolation and concentration steps - may contribute to alter the EVs' contents and therefore their therapeutic potential, thus stressing the need for extensive characterization all throughout the development of the product [40]. On the other hand, ensuring patients' safety during early phase clinical trials constitutes a major concern for such an exploratory treatment. Beyond the collection of extensive preclinical safety data, a consensus should be reached on the best characterization assays and quality controls to perform to check batch quality and sterility. These assays should ideally associate low cost, straightforward protocols, and not be overly time-consuming to remain compatible with clinical practice. Overcoming such hurdles would enable a smooth clinical translation, both for fistula therapy and in other indications.

\section{Conclusion}

Innovative stem/stromal cell-based therapies have provided a major hope for digestive fistulae management. Especially encouraging results were obtained both in terms of safety and efficacy for perianal fistulizing Crohn's disease, where local allogeneic AdSC injection constitutes a clinically accepted therapeutic alternative for patients who are refractory to standard treatment. Though some tentative steps have been made towards the development of a standardized administration protocol, optimizing delivery strategies may tremendously affect treatment efficacy. The cost of such therapies remains one of the major obstacles towards a widespread use in clinical practice. Recently, emerging preclinical evidence has stressed the therapeutic interest of EVs for post-surgical digestive fistulae. While further exploratory studies are warranted, both for post-surgical and Crohn's-associated fistulae, the development of adequate production, isolation and characterization processes still constitutes a necessary first step before clinical translation can be envisioned.

\section{Funding}

This project has received funding from the European Research Council (ERC) under the European Union's Horizon 2020 research and innovation programme (grant agreement No. 852791). This work was supported by Ecole Doctorale Frontières de 1'Innovation en Recherche et Education -Programme Bettencourt. This study was supported by the IdEx Université de Paris, ANR-18-IDEX-0001 and by the Region Ile de France under the convention SESAME 2019 - IVETh (nº EX047011).

\section{Declaration of interest}

Florence Gazeau, Amanda Karine Andriola Silva, Claire Wilhelm and Gabriel Rahmi are co-founders of the spin-off Evora Biosciences. Amanda Karine Andriola Silva and Claire Wilhelm are co-founders of the spin-off EverZom. The other authors have no conflicts to declare.

\section{References}

[1] R.P. Hirten, S. Shah, D.B. Sachar, J.-F. Colombel, The Management of Intestinal Penetrating Crohn's Disease, Inflamm Bowel Dis. 24 (2018) 752-765. https://doi.org/10.1093/ibd/izx108.

[2] I. González-Pinto, E.M. González, Optimising the treatment of upper gastrointestinal fistulae, Gut. 49 (2001) iv21-iv28. https://doi.org/10.1136/gut.49.suppl_4.iv21. 
[3] C.I. Haack, J.R. Galloway, J. Srinivasan, Enterocutaneous Fistulas: A Look at Causes and Management, Curr Surg Rep. 2 (2014) 71. https://doi org/10.1007/s40137-014-0071-0.

[4] S.M. Berry, J.E. Fischer, Classification and pathophysiology of enterocutaneous fistulas, Surg. Clin. North Am. 76 (1996) 1009-1018. https://doi.org/10.1016/s0039-6109(05)70495-3

[5] J. Heimroth, E. Chen, E. Sutton, Management Approaches for Enterocutaneous Fistulas, Am Surg. 84 (2018) 326-333.

[6] S. Cox, R. Brown, A. Millar, A. Numanoglu, A. Alexander, A. Theron, The risks of gastrointestinal injury due to ingested magnetic beads, S. Afr. Med. J. 104 (2014) 277-278. https://doi.org/10.7196/samj.7500

[7] J.-M. Wu, M.-Y. Wang, P.-H. Lee, M.-T. Lin, Gastrojejunocolic fistula after gastrojejunostomy: a case series, J Med Case Rep. 2 (2008) 193. https://doi.org/10.1186/1752-1947-2-193.

[8] G. Garcea, I. Majid, C.D. Sutton, C.J. Pattenden, W.M. Thomas, Diagnosis and management of colovesical fistulae; six-year experience of 90 consecutive cases, Colorectal Dis. 8 (2006) 347352. https://doi.org/10.1111/j.1463-1318.2005.00928.x.

[9] S. Singh, N.S. Ding, K.L. Mathis, P.S. Dulai, A.M. Farrell, J.H. Pemberton, A.L. Hart, W.J. Sandborn, E.V. Loftus, Systematic review with meta-analysis: faecal diversion for management of perianal Crohn's disease, Aliment. Pharmacol. Ther. 42 (2015) 783-792. https://doi.org/10.1111/apt.13356.

[10] D.A. Schwartz, C.R. Herdman, Review article: The medical treatment of Crohn's perianal fistulas, Aliment. Pharmacol. Ther. 19 (2004) 953-967. https://doi.org/10.1111/j.13652036.2004.01917.x.

[11] I. Molendijk, V.J.A.A. Nuij, A.E. van der Meulen-de Jong, C.J. van der Woude, Disappointing durable remission rates in complex Crohn's disease fistula, Inflamm. Bowel Dis. 20 (2014) 2022-2028. https://doi.org/10.1097/MIB.0000000000000148.

[12] F. Bifari, L. Pacelli, M. Krampera, Immunological properties of embryonic and adult stem cells, World Journal of Stem Cells. 2 (2010) 50. https://doi.org/10.4252/wjsc.v2.i3.50.

[13] M. Dominici, K. Le Blanc, I. Mueller, I. Slaper-Cortenbach, F. Marini, D. Krause, R. Deans, A. Keating, D. Prockop, E. Horwitz, Minimal criteria for defining multipotent mesenchymal stromal cells. The International Society for Cellular Therapy position statement, Cytotherapy. 8 (2006) 315-317. https://doi. org/10.1080/14653240600855905.

[14] A.G. Via, A. Frizziero, F. Oliva, Biological properties of mesenchymal Stem Cells from different sources, Muscles, Ligaments and Tendons Journal. 2 (2012) 154

[15] S.-S. Hashemi, A.A. Mohammadi, H. Kabiri, M.R. Hashempoor, M. Mahmoodi, M. Amini, D. Mehrabani, The healing effect of Wharton's jelly stem cells seeded on biological scaffold in chronic skin ulcers: A randomized clinical trial, J Cosmet Dermatol. 18 (2019) 1961-1967. https://doi.org/10.1111/jocd.12931.

[16] A. Saad, A.B. Dietz, S.M.S. Herrmann, L.J. Hickson, J.F. Glockner, M.A. McKusick, S. Misra, H. Bjarnason, A.S. Armstrong, D.A. Gastineau, L.O. Lerman, S.C. Textor, Autologous Mesenchymal Stem Cells Increase Cortical Perfusion in Renovascular Disease, J. Am. Soc. Nephrol. 28 (2017) 2777-2785. https://doi.org/10.1681/ASN.2017020151.

[17] M. Wang, Q. Yuan, L. Xie, Mesenchymal Stem Cell-Based Immunomodulation: Properties and Clinical Application, Stem Cells Int. 2018 (2018). https://doi.org/10.1155/2018/3057624.

[18] X. Li, G. An, Y. Wang, D. Liang, Z. Zhu, L. Tian, Targeted migration of bone marrow mesenchymal stem cells inhibits silica-induced pulmonary fibrosis in rats, Stem Cell Res Ther. 9 (2018) 335. https://doi.org/10.1186/s13287-018-1083-y.

[19] W.-J. Song, Q. Li, M.-O. Ryu, J.-O. Ahn, D. Ha Bhang, Y. Chan Jung, H.-Y. Youn, TSG-6 Secreted by Human Adipose Tissue-derived Mesenchymal Stem Cells Ameliorates DSS-induced colitis by Inducing M2 Macrophage Polarization in Mice, Sci Rep. 7 (2017). https://doi.org/10.1038/s41598-017-04766-7. 
[20] M. François, R. Romieu-Mourez, M. Li, J. Galipeau, Human MSC Suppression Correlates With Cytokine Induction of Indoleamine 2,3-Dioxygenase and Bystander M2 Macrophage Differentiation, Molecular Therapy. 20 (2012) 187-195. https://doi.org/10.1038/mt.2011.189.

[21] K. Németh, A. Leelahavanichkul, P.S.T. Yuen, B. Mayer, A. Parmelee, K. Doi, P.G. Robey, K. Leelahavanichkul, B.H. Koller, J.M. Brown, X. Hu, I. Jelinek, R.A. Star, É. Mezey, Bone marrow stromal cells attenuate sepsis via prostaglandin E2-dependent reprogramming of host macrophages to increase their interleukin-10 production, Nat Med. 15 (2009) 42-49. https://doi.org/10.1038/nm.1905.

[22] J.M. Ryan, F. Barry, J.M. Murphy, B.P. Mahon, Interferon- $\gamma$ does not break, but promotes the immunosuppressive capacity of adult human mesenchymal stem cells, Clin Exp Immunol. 149 (2007) 353-363. https://doi.org/10.1111/j.1365-2249.2007.03422.x.

[23] M. Krampera, L. Cosmi, R. Angeli, A. Pasini, F. Liotta, A. Andreini, V. Santarlasci, B. Mazzinghi, G. Pizzolo, F. Vinante, P. Romagnani, E. Maggi, S. Romagnani, F. Annunziato, Role for Interferon- $\gamma$ in the Immunomodulatory Activity of Human Bone Marrow Mesenchymal Stem Cells, STEM CELLS. 24 (2006) 386-398. https://doi.org/10.1634/stemcells.2005-0008.

[24] A.G. Laing, G. Fanelli, A. Ramirez-Valdez, R.I. Lechler, G. Lombardi, P.T. Sharpe, Mesenchymal stem cells inhibit T-cell function through conserved induction of cellular stress, PLoS One. 14 (2019). https://doi.org/10.1371/journal.pone.0213170.

[25] N. Milosavljevic, M. Gazdic, B.S. Markovic, A. Arsenijevic, J. Nurkovic, Z. Dolicanin, N. Jovicic, I. Jeftic, V. Djonov, N. Arsenijevic, M.L. Lukic, V. Volarevic, Mesenchymal stem cells attenuate liver fibrosis by suppressing Th17 cells - an experimental study, Transplant International. 31 (2018) 102-115. https://doi.org/10.1111/tri.13023.

[26] Q. Ge, H. Zhang, J. Hou, L. Wan, W. Cheng, X. Wang, D. Dong, C. Chen, J. Xia, J. Guo, X. Chen, X. Wu, VEGF secreted by mesenchymal stem cells mediates the differentiation of endothelial progenitor cells into endothelial cells via paracrine mechanisms, Mol Med Rep. 17 (2018) 1667-1675. https://doi.org/10.3892/mmr.2017.8059.

[27] H. Li, R. Daculsi, M. Grellier, R. Bareille, C. Bourget, M. Remy, J. Amedee, The Role of Vascular Actors in Two Dimensional Dialogue of Human Bone Marrow Stromal Cell and Endothelial Cell for Inducing Self-Assembled Network, PLoS One. 6 (2011). https://doi.org/10.1371/journal.pone.0016767.

[28] J.-Y. Li, K.-K. Ren, W.-J. Zhang, L. Xiao, H.-Y. Wu, Q.-Y. Liu, T. Ding, X.-C. Zhang, W.-J. Nie, Y. Ke, K.-Y. Deng, Q.-W. Liu, H.-B. Xin, Human amniotic mesenchymal stem cells and their paracrine factors promote wound healing by inhibiting heat stress-induced skin cell apoptosis and enhancing their proliferation through activating PI3K/AKT signaling pathway, Stem Cell Res Ther. 10 (2019). https://doi.org/10.1186/s13287-019-1366-y.

[29] A. Sémont, C. Demarquay, R. Bessout, C. Durand, M. Benderitter, N. Mathieu, Mesenchymal Stem Cell Therapy Stimulates Endogenous Host Progenitor Cells to Improve Colonic Epithelial Regeneration, PLoS One. 8 (2013). https://doi.org/10.1371/journal.pone.0070170.

[30] M.N.M. Walter, K.T. Wright, H.R. Fuller, S. MacNeil, W.E.B. Johnson, Mesenchymal stem cell-conditioned medium accelerates skin wound healing: an in vitro study of fibroblast and keratinocyte scratch assays, Exp Cell Res. 316 (2010) 1271-1281. https://doi.org/10.1016/j.yexcr.2010.02.026.

[31] E.Y. Lee, Y. Xia, W.-S. Kim, M.H. Kim, T.H. Kim, K.J. Kim, B.-S. Park, J.-H. Sung, Hypoxia-enhanced wound-healing function of adipose-derived stem cells: Increase in stem cell proliferation and up-regulation of VEGF and bFGF, Wound Repair and Regeneration. 17 (2009) 540-547. https://doi.org/10.1111/j.1524-475X.2009.00499.x.

[32] E.K. Jun, Q. Zhang, B.S. Yoon, J.-H. Moon, G. Lee, G. Park, P.J. Kang, J.H. Lee, A. Kim, S. You, Hypoxic Conditioned Medium from Human Amniotic Fluid-Derived Mesenchymal Stem Cells Accelerates Skin Wound Healing through TGF- $\beta$ /SMAD2 and PI3K/Akt Pathways, Int J Mol Sci. 15 (2014) 605-628. https://doi.org/10.3390/ijms15010605. 
[33] J.-G. Gao, M.-S. Yu, M.-M. Zhang, X.-W. Gu, Y. Ren, X.-X. Zhou, D. Chen, T.-L. Yan, Y.M. Li, X. Jin, Adipose-derived mesenchymal stem cells alleviate TNBS-induced colitis in rats by influencing intestinal epithelial cell regeneration, Wnt signaling, and T cell immunity, World J Gastroenterol. 26 (2020) 3750-3766. https://doi.org/10.3748/wjg.v26.i26.3750.

[34] M. Di Nicola, C. Carlo-Stella, M. Magni, M. Milanesi, P.D. Longoni, P. Matteucci, S. Grisanti, A.M. Gianni, Human bone marrow stromal cells suppress T-lymphocyte proliferation induced by cellular or nonspecific mitogenic stimuli, Blood. 99 (2002) 3838-3843. https://doi.org/10.1182/blood.V99.10.3838.

[35] R.C. Lai, T.S. Chen, S.K. Lim, Mesenchymal stem cell exosome: a novel stem cell-based therapy for cardiovascular disease, Regen Med. 6 (2011) 481-492. https://doi.org/10.2217/rme.11.35

[36] L. Liao, B. Shi, H. Chang, X. Su, L. Zhang, C. Bi, Y. Shuai, X. Du, Z. Deng, Y. Jin, Heparin improves BMSC cell therapy: Anticoagulant treatment by heparin improves the safety and therapeutic effect of bone marrow-derived mesenchymal stem cell cytotherapy, Theranostics. 7 (2017) 106-116. https://doi.org/10.7150/thno.16911.

[37] R.C. Lai, R.W.Y. Yeo, S.K. Lim, Mesenchymal stem cell exosomes, Semin. Cell Dev. Biol. 40 (2015) 82-88. https://doi.org/10.1016/j.semcdb.2015.03.001.

[38] M. Piffoux, A. Nicolás-Boluda, V. Mulens-Arias, S. Richard, G. Rahmi, F. Gazeau, C. Wilhelm, A.K.A. Silva, Extracellular vesicles for personalized medicine: The input of physically triggered production, loading and theranostic properties, Adv. Drug Deliv. Rev. 138 (2019) 247258. https://doi.org/10.1016/j.addr.2018.12.009.

[39] M. Yáñez-Mó, P.R.-M. Siljander, Z. Andreu, A.B. Zavec, F.E. Borràs, E.I. Buzas, K. Buzas, E. Casal, F. Cappello, J. Carvalho, E. Colás, A.C. Silva, S. Fais, J.M. Falcon-Perez, I.M. Ghobrial, B. Giebel, M. Gimona, M. Graner, I. Gursel, M. Gursel, N.H.H. Heegaard, A. Hendrix, P. Kierulf, K. Kokubun, M. Kosanovic, V. Kralj-Iglic, E.-M. Krämer-Albers, S. Laitinen, C. Lässer, T. Lener, E. Ligeti, A. Linē, G. Lipps, A. Llorente, J. Lötvall, M. Manček-Keber, A. Marcilla, M. Mittelbrunn, I. Nazarenko, E.N.M.N.-‘t Hoen, T.A. Nyman, L. O’Driscoll, M. Olivan, C. Oliveira, É. Pállinger, H.A. del Portillo, J. Reventós, M. Rigau, E. Rohde, M. Sammar, F. Sánchez-Madrid, N. Santarém, K. Schallmoser, M.S. Ostenfeld, W. Stoorvogel, R. Stukelj, S.G. Van der Grein, M.H. Vasconcelos, M.H.M. Wauben, O. De Wever, Biological properties of extracellular vesicles and their physiological functions, J Extracell Vesicles. 4 (2015). https://doi.org/10.3402/jev.v4.27066.

[40] C. Théry, K.W. Witwer, E. Aikawa, M.J. Alcaraz, J.D. Anderson, R. Andriantsitohaina, A. Antoniou, T. Arab, F. Archer, G.K. Atkin-Smith, D.C. Ayre, J.-M. Bach, D. Bachurski, H. Baharvand, L. Balaj, S. Baldacchino, N.N. Bauer, A.A. Baxter, M. Bebawy, C. Beckham, A.B. Zavec, A. Benmoussa, A.C. Berardi, P. Bergese, E. Bielska, C. Blenkiron, S. Bobis-Wozowicz, E. Boilard, W. Boireau, A. Bongiovanni, F.E. Borràs, S. Bosch, C.M. Boulanger, X. Breakefield, A.M. Breglio, M.Á. Brennan, D.R. Brigstock, A. Brisson, M.L. Broekman, J.F. Bromberg, P. Bryl-Górecka, S. Buch, A.H. Buck, D. Burger, S. Busatto, D. Buschmann, B. Bussolati, E.I. Buzás, J.B. Byrd, G. Camussi, D.R. Carter, S. Caruso, L.W. Chamley, Y.-T. Chang, C. Chen, S. Chen, L. Cheng, A.R. Chin, A. Clayton, S.P. Clerici, A. Cocks, E. Cocucci, R.J. Coffey, A. Cordeiro-da-Silva, Y. Couch, F.A. Coumans, B. Coyle, R. Crescitelli, M.F. Criado, C. D'SouzaSchorey, S. Das, A.D. Chaudhuri, P. de Candia, E.F.D.S. Junior, O.D. Wever, H.A. del Portillo, T. Demaret, S. Deville, A. Devitt, B. Dhondt, D.D. Vizio, L.C. Dieterich, V. Dolo, A.P.D. Rubio, M. Dominici, M.R. Dourado, T.A. Driedonks, F.V. Duarte, H.M. Duncan, R.M. Eichenberger, K. Ekström, S.E. Andaloussi, C. Elie-Caille, U. Erdbrügger, J.M. Falcón-Pérez, F. Fatima, J.E. Fish, M. Flores-Bellver, A. Försönits, A. Frelet-Barrand, F. Fricke, G. Fuhrmann, S. Gabrielsson, A. Gámez-Valero, C. Gardiner, K. Gärtner, R. Gaudin, Y.S. Gho, B. Giebel, C. Gilbert, M. Gimona, I. Giusti, D.C. Goberdhan, A. Görgens, S.M. Gorski, D.W. Greening, J.C. Gross, A. Gualerzi, G.N. Gupta, D. Gustafson, A. Handberg, R.A. Haraszti, P. Harrison, H. Hegyesi, A. Hendrix, A.F. Hill, F.H. Hochberg, K.F. Hoffmann, B. Holder, H. Holthofer, B 
Hosseinkhani, G. Hu, Y. Huang, V. Huber, S. Hunt, A.G.-E. Ibrahim, T. Ikezu, J.M. Inal, M. Isin, A. Ivanova, H.K. Jackson, S. Jacobsen, S.M. Jay, M. Jayachandran, G. Jenster, L. Jiang, S.M. Johnson, J.C. Jones, A. Jong, T. Jovanovic-Talisman, S. Jung, R. Kalluri, S. Kano, S. Kaur, Y. Kawamura, E.T. Keller, D. Khamari, E. Khomyakova, A. Khvorova, P. Kierulf, K.P. Kim, T. Kislinger, M. Klingeborn, D.J.K. II, M. Kornek, M.M. Kosanović, Á.F. Kovács, E.-M. KrämerAlbers, S. Krasemann, M. Krause, I.V. Kurochkin, G.D. Kusuma, S. Kuypers, S. Laitinen, S.M. Langevin, L.R. Languino, J. Lannigan, C. Lässer, L.C. Laurent, G. Lavieu, E. Lázaro-Ibáñez, S.L. Lay, M.-S. Lee, Y.X.F. Lee, D.S. Lemos, M. Lenassi, A. Leszczynska, I.T. Li, K. Liao, S.F. Libregts, E. Ligeti, R. Lim, S.K. Lim, A. Linē, K. Linnemannstöns, A. Llorente, C.A. Lombard, M.J. Lorenowicz, A.M. Lörincz, J. Lötvall, J. Lovett, M.C. Lowry, X. Loyer, Q. Lu, B. Lukomska, T.R. Lunavat, S.L. Maas, H. Malhi, A. Marcilla, J. Mariani, J. Mariscal, E.S. Martens-Uzunova, L. Martin-Jaular, M.C. Martinez, V.R. Martins, M. Mathieu, S. Mathivanan, M. Maugeri, L.K. McGinnis, M.J. McVey, D.G.M. Jr, K.L. Meehan, I. Mertens, V.R Minciacchi, A. Möller, M.M. Jørgensen, A. Morales-Kastresana, J. Morhayim, F. Mullier, M. Muraca, L. Musante, V. Mussack, D.C. Muth, K.H. Myburgh, T. Najrana, M. Nawaz, I. Nazarenko, P. Nejsum, C. Neri, T. Neri, R. Nieuwland, L. Nimrichter, J.P. Nolan, E.N.N.-'t Hoen, N.N. Hooten, L. O'Driscoll, T. O'Grady, A. O’Loghlen, T. Ochiya, M. Olivier, A. Ortiz, L.A. Ortiz, X. Osteikoetxea, O. Østergaard, M. Ostrowski, J. Park, D.M. Pegtel, H. Peinado, F. Perut, M.W. Pfaffl, D.G. Phinney, B.C. Pieters, R.C. Pink, D.S. Pisetsky, E.P. von Strandmann, I. Polakovicova, I.K. Poon, B.H. Powell, I. Prada, L. Pulliam, P. Quesenberry, A. Radeghieri, R.L. Raffai, S. Raimondo, J. Rak, M.I. Ramirez, G. Raposo, M.S. Rayyan, N. Regev-Rudzki, F.L. Ricklefs, P.D. Robbins, D.D. Roberts, S.C. Rodrigues, E. Rohde, S. Rome, K.M. Rouschop, A. Rughetti, A.E. Russell, P. Saá, S. Sahoo, E. Salas-Huenuleo, C. Sánchez, J.A. Saugstad, M.J. Saul, R.M. Schiffelers, R. Schneider, T.H. Schøyen, A. Scott, E. Shahaj, S. Sharma, O. Shatnyeva, F. Shekari, G.V. Shelke, A.K. Shetty, K. Shiba, P.R.-M. Siljander, A.M. Silva, A. Skowronek, O.L.S. II, R.P. Soares, B.W. Sódar, C. Soekmadji, J. Sotillo, P.D. Stahl, W. Stoorvogel, S.L. Stott, E.F. Strasser, S. Swift, H. Tahara, M. Tewari, K. Timms, S. Tiwari, R. Tixeira, M. Tkach, W.S. Toh, R. Tomasini, A.C. Torrecilhas, J.P. Tosar, V. Toxavidis, L. Urbanelli, P. Vader, B.W. van Balkom, S.G. van der Grein, J.V. Deun, M.J. van Herwijnen, K.V. Keuren-Jensen, G. van Niel, M.E. van Royen, A.J. van Wijnen, M.H. Vasconcelos, I.J.V. Jr, T.D. Veit, L.J. Vella, É. Velot, F.J. Verweij, B. Vestad, J.L. Viñas, T. Visnovitz, K.V. Vukman, J. Wahlgren, D.C. Watson, M.H. Wauben, A. Weaver, J.P. Webber, V. Weber, A.M. Wehman, D.J. Weiss, J.A. Welsh, S. Wendt, A.M. Wheelock, Z. Wiener, L. Witte, J. Wolfram, A. Xagorari, P. Xander, J. Xu, X. Yan, M. Yáñez-Mó, H. Yin, Y. Yuana, V. Zappulli, J. Zarubova, V. Žèkas, J. Zhang, Z. Zhao, L. Zheng, A.R. Zheutlin, A.M. Zickler, P. Zimmermann, A.M. Zivkovic, D. Zocco, E.K. Zuba-Surma, Minimal information for studies of extracellular vesicles 2018 (MISEV2018): a position statement of the International Society for Extracellular Vesicles and update of the MISEV2014 guidelines, Journal of Extracellular Vesicles. 7 (2018) 1535750. https://doi.org/10.1080/20013078.2018.1535750.

[41] X. Cheng, G. Zhang, L. Zhang, Y. Hu, K. Zhang, X. Sun, C. Zhao, H. Li, Y.M. Li, J. Zhao, Mesenchymal stem cells deliver exogenous miR- 21 via exosomes to inhibit nucleus pulposus cell apoptosis and reduce intervertebral disc degeneration, J Cell Mol Med. 22 (2018) 261-276. https://doi.org/10.1111/jcmm.13316.

[42] F. Arslan, R.C. Lai, M.B. Smeets, L. Akeroyd, A. Choo, E.N.E. Aguor, L. Timmers, H.V. van Rijen, P.A. Doevendans, G. Pasterkamp, S.K. Lim, D.P. de Kleijn, Mesenchymal stem cellderived exosomes increase ATP levels, decrease oxidative stress and activate PI3K/Akt pathway to enhance myocardial viability and prevent adverse remodeling after myocardial ischemia/reperfusion injury, Stem Cell Research. 10 (2013) 301-312. https://doi.org/10.1016/j.scr.2013.01.002 
[43] S. Kim, S.K. Lee, H. Kim, T.M. Kim, Exosomes Secreted from Induced Pluripotent Stem Cell-Derived Mesenchymal Stem Cells Accelerate Skin Cell Proliferation, Int J Mol Sci. 19 (2018). https://doi.org/10.3390/ijms19103119.

[44] X. Li, L. Liu, J. Yang, Y. Yu, J. Chai, L. Wang, L. Ma, H. Yin, Exosome Derived From Human Umbilical Cord Mesenchymal Stem Cell Mediates MiR-181c Attenuating Burn-induced Excessive Inflammation, EBioMedicine. 8 (2016) 72-82. https://doi.org/10.1016/j.ebiom.2016.04.030

[45] T. Li, Y. Yan, B. Wang, H. Qian, X. Zhang, L. Shen, M. Wang, Y. Zhou, W. Zhu, W. Li, W. $\mathrm{Xu}$, Exosomes Derived from Human Umbilical Cord Mesenchymal Stem Cells Alleviate Liver Fibrosis, Stem Cells Dev. 22 (2013) 845-854. https://doi.org/10.1089/scd.2012.0395.

[46] Y. Wang, J. Tian, X. Tang, K. Rui, X. Tian, J. Ma, B. Ma, H. Xu, L. Lu, S. Wang, Exosomes released by granulocytic myeloid-derived suppressor cells attenuate DSS-induced colitis in mice, Oncotarget. 7 (2016) 15356-15368. https://doi.org/10.18632/oncotarget.7324.

[47] L. Jiang, Y. Shen, D. Guo, D. Yang, J. Liu, X. Fei, Y. Yang, B. Zhang, Z. Lin, F. Yang, X. Wang, K. Wang, J. Wang, Z. Cai, EpCAM-dependent extracellular vesicles from intestinal epithelial cells maintain intestinal tract immune balance, Nat Commun. 7 (2016) 13045. https://doi.org/10.1038/ncomms 13045.

[48] H. Liu, Z. Liang, F. Wang, C. Zhou, X. Zheng, T. Hu, X. He, X. Wu, P. Lan, Exosomes from mesenchymal stromal cells reduce murine colonic inflammation via a macrophage-dependent mechanism, JCI Insight. 4 (2019). https://doi.org/10.1172/jci.insight. 131273.

[49] Q. Chen, X. Duan, M. Xu, H. Fan, Y. Dong, H. Wu, M. Zhang, Y. Liu, Z. Nan, S. Deng, X Liu, BMSC-EVs regulate Th17 cell differentiation in UC via H3K27me3, Mol. Immunol. 118 (2020) 191-200. https://doi.org/10.1016/j.molimm.2019.12.019.

[50] M. Gong, B. Yu, J. Wang, Y. Wang, M. Liu, C. Paul, R.W. Millard, D.-S. Xiao, M. Ashraf, M. Xu, Mesenchymal stem cells release exosomes that transfer miRNAs to endothelial cells and promote angiogenesis, Oncotarget. 8 (2017) 45200-45212. https://doi.org/10.18632/oncotarget. 16778 .

[51] P. Gangadaran, R.L. Rajendran, H.W. Lee, S. Kalimuthu, C.M. Hong, S.Y. Jeong, S.-W. Lee, J. Lee, B.-C. Ahn, Extracellular vesicles from mesenchymal stem cells activates VEGF receptors and accelerates recovery of hindlimb ischemia, J Control Release. 264 (2017) 112-126. https://doi.org/10.1016/j.jconrel.2017.08.022.

[52] J. Yang, X.-X. Liu, H. Fan, Q. Tang, Z.-X. Shou, D.-M. Zuo, Z. Zou, M. Xu, Q.-Y. Chen, Y. Peng, S.-J. Deng, Y.-J. Liu, Extracellular Vesicles Derived from Bone Marrow Mesenchymal Stem Cells Protect against Experimental Colitis via Attenuating Colon Inflammation, Oxidative Stress and Apoptosis, PLoS ONE. 10 (2015) e0140551. https://doi.org/10.1371/journal.pone.0140551.

[53] G. Leoni, P.-A. Neumann, N. Kamaly, M. Quiros, H. Nishio, H.R. Jones, R. Sumagin, R. S. Hilgarth, A. Alam, G. Fredman, I. Argyris, E. Rijcken, D. Kusters, C. Reutelingsperger, M. Perretti, C.A. Parkos, O.C. Farokhzad, A.S. Neish, A. Nusrat, Annexin Al-containing extracellular vesicles and polymeric nanoparticles promote epithelial wound repair, J Clin Invest. 125 (2015) 1215-1227. https://doi.org/10.1172/JCI76693

[54] A. da F. Ferreira, P. da S. Cunha, V.M. Carregal, P. de C. da Silva, M.C. de Miranda, M. Kunrath-Lima, M.I.A. de Melo, C.C.F. Faraco, J.L. Barbosa, F. Frezard, V. Resende, M.A. Rodrigues, A.M. de Goes, D.A. Gomes, Extracellular Vesicles from Adipose-Derived Mesenchymal Stem/Stromal Cells Accelerate Migration and Activate AKT Pathway in Human Keratinocytes and Fibroblasts Independently of miR-205 Activity, Stem Cells Int. 2017 (2017). https://doi.org/10.1155/2017/9841035.

[55] S. Bruno, C. Grange, M.C. Deregibus, R.A. Calogero, S. Saviozzi, F. Collino, L. Morando, A. Busca, M. Falda, B. Bussolati, C. Tetta, G. Camussi, Mesenchymal Stem Cell-Derived Microvesicles Protect Against Acute Tubular Injury, J Am Soc Nephrol. 20 (2009) 1053-1067. https://doi.org/10.1681/ASN.2008070798 
[56] Y. Sun, H. Shi, S. Yin, C. Ji, X. Zhang, B. Zhang, P. Wu, Y. Shi, F. Mao, Y. Yan, W. Xu, H. Qian, Human Mesenchymal Stem Cell Derived Exosomes Alleviate Type 2 Diabetes Mellitus by Reversing Peripheral Insulin Resistance and Relieving $\beta$-Cell Destruction, ACS Nano. 12 (2018) 7613-7628. https://doi.org/10.1021/acsnano.7b07643.

[57] A.K.A. Silva, S. Perretta, G. Perrod, L. Pidial, V. Lindner, F. Carn, S. Lemieux, D. Alloyeau, I. Boucenna, P. Menasché, B. Dallemagne, F. Gazeau, C. Wilhelm, C. Cellier, O. Clément, G. Rahmi, Thermoresponsive Gel Embedded with Adipose Stem-Cell-Derived Extracellular Vesicles Promotes Esophageal Fistula Healing in a Thermo-Actuated Delivery Strategy, ACS Nano. 12 (2018) 9800-9814. https://doi.org/10.1021/acsnano.8b00117.

[58] A. Berger, I. Araújo-Filho, M. Piffoux, A. Nicolás-Boluda, A. Grangier, I. Boucenna, C.C. Real, F.L.N. Marques, D. de Paula Faria, A.C.M. do Rego, C. Broudin, F. Gazeau, C. Wilhelm, O. Clément, C. Cellier, C.A. Buchpiguel, G. Rahmi, A.K.A. Silva, Local administration of stem cell-derived extracellular vesicles in a thermoresponsive hydrogel promotes a pro-healing effect in a rat model of colo-cutaneous post-surgical fistula, Nanoscale. 13 (2021) 218-232. https://doi.org/10.1039/d0nr07349k.

[59] S. Choi, B.G. Jeon, G. Chae, S.-J. Lee, The clinical efficacy of stem cell therapy for complex perianal fistulas: a meta-analysis, Tech Coloproctol. 23 (2019) 411-427. https://doi.org/10.1007/s10151-019-01994-z.

[60] S.K. Narang, K. Keogh, N.N. Alam, S. Pathak, I.R. Daniels, N.J. Smart, A systematic review of new treatments for cryptoglandular fistula in ano, Surgeon. 15 (2017) 30-39. https://doi.org/10.1016/j. surge.2016.02.002.

[61] P. Pessaux, S. Msika, D. Atalla, J.-M. Hay, Y. Flamant, French Association for Surgical Research, Risk factors for postoperative infectious complications in noncolorectal abdominal surgery: a multivariate analysis based on a prospective multicenter study of 4718 patients, Arch Surg. 138 (2003) 314-324. https://doi.org/10.1001/archsurg. 138.3.314.

[62] V.M. Prunoiu, A.M. Marincas, C. Pantis, A. Bene, E. Bratucu, S. Ionescu, A. Grigorescu, The Importance of the Nutritional Factor and the Stage of the Disease in Postoperative Fistula in Patients with Gastric Cancer, Chirurgia (Bucur). 114 (2019) 259-267. https://doi.org/10.21614/chirurgia.114.2.259.

[63] M.F.K.P. Ramos, M.A. Pereira, L.C. Barchi, O.K. Yagi, A.R. Dias, D.J. Szor, B. Zilberstein, U. Ribeiro-Júnior, I. Cecconello, Duodenal fistula: The most lethal surgical complication in a case series of radical gastrectomy, Int J Surg. 53 (2018) 366-370. https://doi.org/10.1016/j.ijsu.2018.03.082.

[64] M. Penna, R. Hompes, S. Arnold, G. Wynn, R. Austin, J. Warusavitarne, B. Moran, G.B. Hanna, N.J. Mortensen, P.P. Tekkis, International TaTME Registry Collaborative, Incidence and Risk Factors for Anastomotic Failure in 1594 Patients Treated by Transanal Total Mesorectal Excision: Results From the International TaTME Registry, Ann. Surg. 269 (2019) 700-711. https://doi.org/10.1097/SLA.0000000000002653.

[65] N. Pal, Intestinal Fistula Surgery: Practice Essentials, Pathophysiology, Etiology, (2019). https://emedicine.medscape.com/article/197486-overview\#a8 (accessed June 11, 2020).

[66] T.B. Hugh, M.J. Coleman, A. Cohen, Persistent postoperative enterocutaneous fistula: pathophysiology and treatment, Aust N Z J Surg. 56 (1986) 901-906. https://doi.org/10.1111/j.1445-2197.1986.tb01852.x.

[67] I.T.A. Pereboom, H.S. Hofker, A Mechanical Explanation for the Development of Enteroatmospheric Fistulas in Open Abdomen, Dis. Colon Rectum. 59 (2016) 471-475. https://doi.org/10.1097/DCR.0000000000000559.

[68] P. Hollington, J. Mawdsley, W. Lim, S.M. Gabe, A. Forbes, A.J. Windsor, An 11-year experience of enterocutaneous fistula, Br J Surg. 91 (2004) 1646-1651. https://doi.org/10.1002/bjs.4788.

[69] N. Kaur, V.R. Minocha, Review of a hospital experience of enterocutaneous fistula, Trop Gastroenterol. 21 (2000) 197-200. 
[70] P. Kumar, N.K. Maroju, V. Kate, Enterocutaneous fístulae: etiology, treatment, and outcome - a study from South India, Saudi J Gastroenterol. 17 (2011) 391-395. https://doi.org/10.4103/1319-3767.87180.

[71] M. Quinn, S. Falconer, R.F. McKee, Management of Enterocutaneous Fistula: Outcomes in 276 Patients, World J Surg. 41 (2017) 2502-2511. https://doi.org/10.1007/s00268-017-4063-y.

[72] T.M. Mackay, F.J. Smits, D. Roos, B.A. Bonsing, K. Bosscha, O.R. Busch, G.-J. Creemers, R.M. van Dam, C.H.J. van Eijck, M.F. Gerhards, J.W.B. de Groot, B. Groot Koerkamp, N. Haj Mohammad, E. van der Harst, I.H.J.T. de Hingh, M.Y.V. Homs, G. Kazemier, M.S.L. Liem, V.E. de Meijer, I.Q. Molenaar, V.B. Nieuwenhuijs, H.C. van Santvoort, G.P. van der Schelling, M.W.J. Stommel, A.J. Ten Tije, J. de Vos-Geelen, F. Wit, J.W. Wilmink, H.W.M. van Laarhoven, M.G. Besselink, Dutch Pancreatic Cancer Group, The risk of not receiving adjuvant chemotherapy after resection of pancreatic ductal adenocarcinoma: a nationwide analysis, HPB (Oxford). 22 (2020) 233-240. https://doi.org/10.1016/j.hpb.2019.06.019.

[73] C.B. Nahm, S.J. Connor, J.S. Samra, A. Mittal, Postoperative pancreatic fistula: a review of traditional and emerging concepts, Clin Exp Gastroenterol. 11 (2018) 105-118. https://doi.org/10.2147/CEG. S120217.

[74] J. Burisch, T. Jess, M. Martinato, P.L. Lakatos, The burden of inflammatory bowel disease in Europe, Journal of Crohn's and Colitis. 7 (2013) 322-337. https://doi.org/10.1016/j.crohns.2013.01.010.

[75] M. Rohr, C.A. Narasimhulu, D. Sharma, M. Doomra, A. Riad, S. Naser, S. Parthasarathy, Inflammatory Diseases of the Gut, J Med Food. 21 (2018) 113-126. https://doi.org/10.1089/jmf.2017.0138.

[76] S. Flynn, S. Eisenstein, Inflammatory Bowel Disease Presentation and Diagnosis, Surg. Clin North Am. 99 (2019) 1051-1062. https://doi. org/10.1016/j. suc.2019.08.001.

[77] J.-P. Hugot, M. Chamaillard, H. Zouali, S. Lesage, J.-P. Cézard, J. Belaiche, S. Almer, C. Tysk, C.A. O'Morain, M. Gassull, V. Binder, Y. Finkel, A. Cortot, R. Modigliani, P. LaurentPuig, C. Gower-Rousseau, J. Macry, J.-F. Colombel, M. Sahbatou, G. Thomas, Association of NOD2 leucine-rich repeat variants with susceptibility to Crohn's disease, Nature. 411 (2001) 599-603. https://doi.org/10.1038/35079107.

[78] A.N. Ananthakrishnan, C.N. Bernstein, D. Iliopoulos, A. Macpherson, M.F. Neurath, R.A.R Ali, S.R. Vavricka, C. Fiocchi, Environmental triggers in IBD: a review of progress and evidence, Nat Rev Gastroenterol Hepatol. 15 (2018) 39-49. https://doi.org/10.1038/nrgastro.2017.136.

[79] R.J. Xavier, D.K. Podolsky, Unravelling the pathogenesis of inflammatory bowel disease, Nature. 448 (2007) 427-434. https://doi.org/10.1038/nature06005

[80] R.B. Sartor, G.D. Wu, Roles for Intestinal Bacteria, Viruses, and Fungi in Pathogenesis of Inflammatory Bowel Diseases and Therapeutic Approaches, Gastroenterology. 152 (2017) 327339.e4. https://doi.org/10.1053/j.gastro.2016.10.012.

[81] S.N. Leeb, D. Vogl, M. Gunckel, S. Kiessling, W. Falk, M. Göke, J. Schölmerich, C.M. Gelbmann, G. Rogler, Reduced migration of fibroblasts in inflammatory bowel disease: role of inflammatory mediators and focal adhesion kinase1, Gastroenterology. 125 (2003) 1341-1354. https://doi.org/10.1016/j.gastro.2003.07.004.

[82] M. Scharl, G. Rogler, Pathophysiology of fistula formation in Crohn's disease, World J Gastrointest Pathophysiol. 5 (2014) 205-212. https://doi.org/10.4291/wjgp.v5.i3.205.

[83] J. Panés, J. Rimola, Perianal fistulizing Crohn's disease: pathogenesis, diagnosis and therapy, Nat Rev Gastroenterol Hepatol. 14 (2017) 652-664. https://doi. org/10.1038/nrgastro.2017.104.

[84] F. Bataille, C. Rohrmeier, R. Bates, A. Weber, F. Rieder, J. Brenmoehl, U. Strauch, S. Farkas, A. Fürst, F. Hofstädter, J. Schölmerich, H. Herfarth, G. Rogler, Evidence for a role of epithelial mesenchymal transition during pathogenesis of fistulae in Crohn's disease, Inflamm. Bowel Dis. 14 (2008) 1514-1527. https://doi.org/10.1002/ibd.20590. 
[85] F. Makowiec, E.C. Jehle, M. Starlinger, Clinical course of perianal fistulas in Crohn's disease, Gut. 37 (1995) 696-701. https://doi.org/10.1136/gut.37.5.696.

[86] J. Torres, S. Bonovas, G. Doherty, T. Kucharzik, J.P. Gisbert, T. Raine, M. Adamina, A. Armuzzi, O. Bachmann, P. Bager, L. Biancone, B. Bokemeyer, P. Bossuyt, J. Burisch, P. Collins, A. El-Hussuna, P. Ellul, C. Frei-Lanter, F. Furfaro, C. Gingert, P. Gionchetti, F. Gomollon, M. González-Lorenzo, H. Gordon, T. Hlavaty, P. Juillerat, K. Katsanos, U. Kopylov, E. Krustins, T. Lytras, C. Maaser, F. Magro, J. Kenneth Marshall, P. Myrelid, G. Pellino, I. Rosa, J. Sabino, E. Savarino, A. Spinelli, L. Stassen, M. Uzzan, S. Vavricka, B. Verstockt, J. Warusavitarne, O. Zmora, G. Fiorino, ECCO Guidelines on Therapeutics in Crohn's Disease: Medical Treatment, Journal of Crohn's and Colitis. 14 (2020) 4-22. https://doi.org/10.1093/ecco-jcc/jjz180.

[87] M. Adamina, S. Bonovas, T. Raine, A. Spinelli, J. Warusavitarne, A. Armuzzi, O. Bachmann, P. Bager, L. Biancone, B. Bokemeyer, P. Bossuyt, J. Burisch, P. Collins, G. Doherty, A. ElHussuna, P. Ellul, G. Fiorino, C. Frei-Lanter, F. Furfaro, C. Gingert, P. Gionchetti, J.P. Gisbert, F. Gomollon, M. González Lorenzo, H. Gordon, T. Hlavaty, P. Juillerat, K. Katsanos, U. Kopylov, E. Krustins, T. Kucharzik, T. Lytras, C. Maaser, F. Magro, J.K. Marshall, P. Myrelid, G. Pellino, I. Rosa, J. Sabino, E. Savarino, L. Stassen, J. Torres, M. Uzzan, S. Vavricka, B. Verstockt, O. Zmora, ECCO Guidelines on Therapeutics in Crohn's Disease: Surgical Treatment, Journal of Crohn's and Colitis. 14 (2020) 155-168. https://doi.org/10.1093/eccojcc/jjz187.

[88] B.E. Sands, F.H. Anderson, C.N. Bernstein, W.Y. Chey, B.G. Feagan, R.N. Fedorak, M.A. Kamm, J.R. Korzenik, B.A. Lashner, J.E. Onken, D. Rachmilewitz, P. Rutgeerts, G. Wild, D.C. Wolf, P.A. Marsters, S.B. Travers, M.A. Blank, S.J. van Deventer, Infliximab maintenance therapy for fistulizing Crohn's disease, N Engl J Med. 350 (2004) 876-885. https://doi.org/10.1056/NEJMoa030815.

[89] P. Rogalski, J. Daniluk, A. Baniukiewicz, E. Wroblewski, A. Dabrowski, Endoscopic management of gastrointestinal perforations, leaks and fistulas, World J. Gastroenterol. 21 (2015) 10542-10552. https://doi.org/10.3748/wjg.v21.i37.10542.

[90] J. Avalos-González, E. Portilla-deBuen, C.A. Leal-Cortés, A. Orozco-Mosqueda, M. del C. Estrada-Aguilar, G.A. Velázquez-Ramírez, G. Ambriz-González, C. Fuentes-Orozco, A.E. Guzmán-Gurrola, A. González-Ojeda, Reduction of the closure time of postoperative enterocutaneous fistulas with fibrin sealant, World J. Gastroenterol. 16 (2010) 2793-2800. https://doi.org/10.3748/wjg.v16.i22.2793.

[91] G. Mauri, L.C. Pescatori, C. Mattiuz, D. Poretti, V. Pedicini, F. Melchiorre, U. Rossi, L. Solbiati, L.M. Sconfienza, Non-healing post-surgical fistulae: treatment with image-guided percutaneous injection of cyanoacrylic glue, Radiol Med. 122 (2017) 88-94. https://doi.org/10.1007/s11547-016-0693-7.

[92] A. Berger, E. Caudron, G. Perrod, I. Boucenna, F. Gazeau, C. Wilhelm, A. Berger, O. Clément, C. Cellier, A.K.A. Silva, G. Rahmi, Enhancing digestive fistula healing by the off-label use of a thermoresponsive vessel occluder polymer associated with esophageal stent placement: A case report, Clin Res Hepatol Gastroenterol. (2020) 101474. https://doi.org/10.1016/j.clinre.2020.06.001.

[93] A. Caziuc, G. Calin Dindelegan, E. Pall, A. Mironiuc, Stem cells improve the quality of colonic anastomoses - A systematic review, J BUON. 20 (2015) 1624-1629.

[94] T. Tanaka, T. Kuroki, T. Adachi, S. Ono, A. Kitasato, M. Hirabaru, M. Takatsuki, S. Eguchi, Development of a novel rat model with pancreatic fistula and the prevention of this complication using tissue-engineered myoblast sheets, J. Gastroenterol. 48 (2013) 1081-1089.

https://doi.org/10.1007/s00535-012-0706-9.

[95] H. Kaneko, T. Kokuryo, Y. Yokoyama, J. Yamaguchi, T. Yamamoto, R. Shibata, M. Gotoh, T. Murohara, A. Ito, M. Nagino, Novel therapy for pancreatic fistula using adipose-derived stem 
cell sheets treated with mannose, Surgery. 161 (2017) 1561-1569.

https://doi.org/10.1016/j.surg. 2016.12.022

[96] S.-R. Kim, H.-J. Yi, Y.N. Lee, J.Y. Park, R.M. Hoffman, T. Okano, I.K. Shim, S.C. Kim, Engineered mesenchymal stem-cell-sheets patches prevents postoperative pancreatic leakage in a rat model, Sci Rep. 8 (2018) 360. https://doi.org/10.1038/s41598-017-18490-9.

[97] B.B. Volpe, A. da S.S. Duarte, T.B. Ribeiro, I. Stocchero, P. Kharmandayan, S.T.O. Saad, J.M. Bustorff-Silva, A.C.M. Luzo, Mesenchymal stromal cells from adipose tissue attached to suture material enhance the closure of enterocutaneous fistulas in a rat model, Cytotherapy. 16 (2014) 1709-1719. https://doi.org/10.1016/j.jcyt.2014.08.004

[98] S.M. Aldaqal, M.F. Khayat, R.Y. Bokhary, M.M. Wakka, A.A. Merdad, L.A. Merdad, Management of postoperative gastrointestinal leakage with autologous stromal vascular fraction, Int Surg. 100 (2015) 748-754. https://doi.org/10.9738/INTSURG-D-14-00120.1.

[99] G. Rahmi, L. Pidial, A.K.A. Silva, E. Blondiaux, B. Meresse, F. Gazeau, G. Autret, D. Balvay, C.A. Cuenod, S. Perretta, B. Tavitian, C. Wilhelm, C. Cellier, O. Clément, Designing 3D Mesenchymal Stem Cell Sheets Merging Magnetic and Fluorescent Features: When Cell Sheet Technology Meets Image-Guided Cell Therapy, Theranostics. 6 (2016) 739-751. https://doi.org/10.7150/thno. 14064 .

[100] O. Ryska, Z. Serclova, O. Mestak, E. Matouskova, P. Vesely, I. Mrazova, Local application of adipose-derived mesenchymal stem cells supports the healing of fistula: prospective randomised study on rat model of fistulising Crohn's disease, Scandinavian Journal of Gastroenterology. 52 (2017) 543-550. https://doi.org/10.1080/00365521.2017.1281434.

[101] T. Mizushima, H. Takahashi, H. Takeyama, A. Naito, N. Haraguchi, M. Uemura, J. Nishimura, T. Hata, I. Takemasa, H. Yamamoto, Y. Doki, M. Mori, A clinical trial of autologous adipose-derived regenerative cell transplantation for a postoperative enterocutaneous fistula, Surg. Today. 46 (2016) 835-842. https://doi.org/10.1007/s00595-015-1246-8.

[102] A.B. Dietz, E.J. Dozois, J.G. Fletcher, G.W. Butler, D. Radel, A.L. Lightner, M. Dave, J. Friton, A. Nair, E.T. Camilleri, A. Dudakovic, A.J. van Wijnen, W.A. Faubion, Autologous Mesenchymal Stem Cells, Applied in a Bioabsorbable Matrix, for Treatment of Perianal Fistulas in Patients With Crohn's Disease, Gastroenterology. 153 (2017) 59-62.e2. https://doi.org/10.1053/j.gastro.2017.04.001.

[103] A.L. Lightner, E.J. Dozois, A.B. Dietz, J.G. Fletcher, J. Friton, G. Butler, W.A. Faubion, Matrix-Delivered Autologous Mesenchymal Stem Cell Therapy for Refractory Rectovaginal Crohn's Fistulas, Inflamm. Bowel Dis. (2019). https://doi.org/10.1093/ibd/izz215.

[104] E.J. Dozois, A.L. Lightner, K.L. Mathis, H.K. Chua, S.R. Kelley, J.G. Fletcher, A.B. Dietz, J.J. Friton, G.W. Butler, W.A. Faubion, Early Results of a Phase I Trial Using an AdiposeDerived Mesenchymal Stem Cell-Coated Fistula Plug for the Treatment of Transsphincteric Cryptoglandular Fistulas, Dis. Colon Rectum. 62 (2019) 615-622. https://doi.org/10.1097/DCR.0000000000001333.

[105] J. Rivera-Nieves, G. Bamias, A. Vidrich, M. Marini, T.T. Pizarro, M.J. McDuffie, C.A. Moskaluk, S.M. Cohn, F. Cominelli, Emergence of perianal fistulizing disease in the SAMP1/YitFc mouse, a spontaneous model of chronic ileitis, Gastroenterology. 124 (2003) 972982. https://doi.org/10.1053/gast.2003.50148

[106] L. Ferrer, E.A. Kimbrel, A. Lam, E.B. Falk, C. Zewe, T. Juopperi, R. Lanza, A. Hoffman, Treatment of perianal fistulas with human embryonic stem cell-derived mesenchymal stem cells: a canine model of human fistulizing Crohn's disease, Regen Med. 11 (2016) 33-43. https://doi.org/10.2217/rme.15.69.

[107] C.L. Cain, Canine Perianal Fistulas: Clinical Presentation, Pathogenesis, and Management, Vet. Clin. North Am. Small Anim. Pract. 49 (2019) 53-65. https://doi.org/10.1016/j.cvsm.2018.08.006.

[108] A.M. Hoffman, S.W. Dow, Concise Review: Stem Cell Trials Using Companion Animal Disease Models, Stem Cells. 34 (2016) 1709-1729. https://doi.org/10.1002/stem.2377. 
[109] M. Flacs, M. Collard, S. Doblas, M. Zappa, D. Cazals-Hatem, L. Maggiori, Y. Panis, X. Treton, E. Ogier-Denis, Preclinical Model of Perianal Fistulizing Crohn's Disease, Inflamm. Bowel Dis. (2019). https://doi.org/10.1093/ibd/izz288.

[110] J.C. Hoffmann, N.N. Pawlowski, A.A. Kühl, W. Höhne, M. Zeitz, Animal models of inflammatory bowel disease: an overview, Pathobiology. 70 (2002) 121-130. https://doi.org/10.1159/000068143.

[111] E. Antoniou, G.A. Margonis, A. Angelou, A. Pikouli, P. Argiri, I. Karavokyros, A. Papalois, E. Pikoulis, The TNBS-induced colitis animal model: An overview, Annals of Medicine and Surgery. 11 (2016) 9-15. https://doi.org/10.1016/j.amsu.2016.07.019.

[112] R.S. Bruckner, E. Nissim-Eliraz, N. Marsiano, E. Nir, H. Shemesh, M. Leutenegger, C. Gottier, S. Lang, M.R. Spalinger, S. Leibl, G. Rogler, S. Yagel, M. Scharl, N.Y. Shpigel, Transplantation of Human Intestine Into the Mouse: A Novel Platform for Study of Inflammatory Enterocutaneous Fistulas, J Crohns Colitis. 13 (2019) 798-806. https://doi.org/10.1093/ecco-jcc/jjy226.

[113] D. García-Olmo, M. García-Arranz, L.G. García, E.S. Cuellar, I.F. Blanco, L.A. Prianes, J.A.R. Montes, F.L. Pinto, D.H. Marcos, L. García-Sancho, Autologous stem cell transplantation for treatment of rectovaginal fistula in perianal Crohn's disease: a new cell-based therapy, Int J Colorectal Dis. 18 (2003) 451-454. https://doi.org/10.1007/s00384-003-0490-3.

[114] D. García-Olmo, M. García-Arranz, D. Herreros, I. Pascual, C. Peiro, J.A. Rodríguez-Montes, A phase I clinical trial of the treatment of Crohn's fistula by adipose mesenchymal stem cell transplantation, Dis. Colon Rectum. 48 (2005) 1416-1423. https://doi.org/10.1007/s10350-0050052-6.

[115] D. Garcia-Olmo, D. Herreros, I. Pascual, J.A. Pascual, E. Del-Valle, J. Zorrilla, P. De-LaQuintana, M. Garcia-Arranz, M. Pascual, Expanded adipose-derived stem cells for the treatment of complex perianal fistula: a phase II clinical trial, Dis. Colon Rectum. 52 (2009) 79-86. https://doi.org/10.1007/DCR.0b013e3181973487.

[116] D. Garcia-Olmo, D. Herreros, M. Pascual, I. Pascual, P. De-La-Quintana, J. Trebol, M. Garcia-Arranz, Treatment of enterocutaneous fistula in Crohn's Disease with adipose-derived stem cells: a comparison of protocols with and without cell expansion, Int J Colorectal Dis. 24 (2009) 27-30. https://doi.org/10.1007/s00384-008-0559-0.

[117] D. García-Olmo, D. Herreros, P. De-La-Quintana, H. Guadalajara, J. Trébol, T. GeorgievHristov, M. García-Arranz, Adipose-derived stem cells in Crohn's rectovaginal fistula, Case Rep Med. 2010 (2010) 961758. https://doi.org/10.1155/2010/961758.

[118] R. Ciccocioppo, M.E. Bernardo, A. Sgarella, R. Maccario, M.A. Avanzini, C. Ubezio, A. Minelli, C. Alvisi, A. Vanoli, F. Calliada, P. Dionigi, C. Perotti, F. Locatelli, G.R. Corazza, Autologous bone marrow-derived mesenchymal stromal cells in the treatment of fistulising Crohn's disease, Gut. 60 (2011) 788-798. https://doi.org/10.1136/gut.2010.214841.

[119] H. Guadalajara, D. Herreros, P. De-La-Quintana, J. Trebol, M. Garcia-Arranz, D. GarciaOlmo, Long-term follow-up of patients undergoing adipose-derived adult stem cell administration to treat complex perianal fistulas, Int J Colorectal Dis. 27 (2012) 595-600. https://doi.org/10.1007/s00384-011-1350-1.

[120] Y.B. Cho, W.Y. Lee, K.J. Park, M. Kim, H.-W. Yoo, C.S. Yu, Autologous adipose tissuederived stem cells for the treatment of Crohn's fistula: a phase I clinical study, Cell Transplant. 22 (2013) 279-285. https://doi.org/10.3727/096368912X656045.

[121] F. de la Portilla, F. Alba, D. García-Olmo, J.M. Herrerías, F.X. González, A. Galindo, Expanded allogeneic adipose-derived stem cells (eASCs) for the treatment of complex perianal fistula in Crohn's disease: results from a multicenter phase I/IIa clinical trial, Int J Colorectal Dis. 28 (2013) 313-323. https://doi.org/10.1007/s00384-012-1581-9.

[122] W.Y. Lee, K.J. Park, Y.B. Cho, S.N. Yoon, K.H. Song, D.S. Kim, S.H. Jung, M. Kim, H.-W. Yoo, I. Kim, H. Ha, C.S. Yu, Autologous adipose tissue-derived stem cells treatment 
demonstrated favorable and sustainable therapeutic effect for Crohn's fistula, Stem Cells. 31 (2013) 2575-2581. https://doi.org/10.1002/stem.1357.

[123] D. Garcia-Olmo, H. Guadalajara, I. Rubio-Perez, M.D. Herreros, P. de-la-Quintana, M. Garcia-Arranz, Recurrent anal fistulae: limited surgery supported by stem cells, World J. Gastroenterol. 21 (2015) 3330-3336. https://doi.org/10.3748/wjg.v21.i11.3330.

[124] Y.B. Cho, K.J. Park, S.N. Yoon, K.H. Song, D.S. Kim, S.H. Jung, M. Kim, H.Y. Jeong, C.S $\mathrm{Yu}$, Long-term results of adipose-derived stem cell therapy for the treatment of Crohn's fistula, Stem Cells Transl Med. 4 (2015) 532-537. https://doi.org/10.5966/sctm.2014-0199.

[125] R. Ciccocioppo, A. Gallia, A. Sgarella, P. Kruzliak, P.G. Gobbi, G.R. Corazza, Long-Term Follow-Up of Crohn Disease Fistulas After Local Injections of Bone Marrow-Derived Mesenchymal Stem Cells, Mayo Clin. Proc. 90 (2015) 747-755.

https://doi.org/10.1016/j.mayocp.2015.03.023.

[126] I. Molendijk, B.A. Bonsing, H. Roelofs, K.C.M.J. Peeters, M.N.J.M. Wasser, G. Dijkstra, C.J. van der Woude, M. Duijvestein, R.A. Veenendaal, J.-J. Zwaginga, H.W. Verspaget, W.E. Fibbe, A.E. van der Meulen-de Jong, D.W. Hommes, Allogeneic Bone Marrow-Derived Mesenchymal Stromal Cells Promote Healing of Refractory Perianal Fistulas in Patients With Crohn's Disease, Gastroenterology. 149 (2015) 918-927.e6.

https://doi.org/10.1053/j.gastro.2015.06.014.

[127] K.J. Park, S.-B. Ryoo, J.S. Kim, T.I. Kim, S.H. Baik, H.J. Kim, K.Y. Lee, M. Kim, W.H. Kim, Allogeneic adipose-derived stem cells for the treatment of perianal fistula in Crohn's disease: a pilot clinical trial, Colorectal Dis. 18 (2016) 468-476. https://doi.org/10.1111/codi.13223.

[128] M. García-Arranz, M.D. Herreros, C. González-Gómez, P. de la Quintana, H. Guadalajara, T. Georgiev-Hristov, J. Trébol, D. Garcia-Olmo, Treatment of Crohn's-Related Rectovaginal Fistula With Allogeneic Expanded-Adipose Derived Stem Cells: A Phase I-IIa Clinical Trial, Stem Cells Transl Med. 5 (2016) 1441-1446. https://doi.org/10.5966/sctm.2015-0356.

[129] A. Moniuszko, A. Sarnowska, W. Rogowski, M. Durlik, A. Wluka, G. Rydzewska, Successful treatment of an enterovesical fistula due to Crohn's disease with stem cell transplantation: a case report, Prz Gastroenterol. 13 (2018) 332-336. https://doi.org/10.5114/pg.2018.79814.

[130] J. Panés, D. García-Olmo, G.V. Assche, J.F. Colombel, W. Reinisch, D.C. Baumgart, A. Dignass, M. Nachury, M. Ferrante, L. Kazemi-Shirazi, J.C. Grimaud, F. de la Portilla, E. Goldin, M.P. Richard, A. Leselbaum, S. Danese, Expanded allogeneic adipose-derived mesenchymal stem cells (Cx601) for complex perianal fistulas in Crohn's disease: a phase 3 randomised, double-blind controlled trial, The Lancet. 388 (2016) 1281-1290. https://doi.org/10.1016/S01406736(16)31203-X.

[131] C. Wainstein, R. Quera, U. Kronberg, A. Conejero, F. López-Kostner, C. Jofre, A.J. Zarate, Mesenchymal stem cells and platelet-rich plasma in the treatment of patients with perineal Crohn's disease, Int J Colorectal Dis. 31 (2016) 725-726. https://doi.org/10.1007/s00384-0152221-y.

[132] C. Wainstein, R. Quera, D. Fluxá, U. Kronberg, A. Conejero, F. López-Köstner, C. Jofre, A.J. Zarate, Stem Cell Therapy in Refractory Perineal Crohn's Disease: Long-term Follow-up, Colorectal Dis. (2018). https://doi.org/10.1111/codi.14002.

[133] M.D. Herreros, D. Garcia-Olmo, H. Guadalajara, T. Georgiev-Hristov, L. Brandariz, M. Garcia-Arranz, Stem Cell Therapy: A Compassionate Use Program in Perianal Fistula, Stem Cells Int. 2019 (2019) 6132340. https://doi.org/10.1155/2019/6132340.

[134] C. Philandrianos, M. Serrero, F. Grimaud, J. Magalon, C. Visée, M. Velier, P. Francois, P. Orsoni, G. Magalon, J.-C. Grimaud, A. Desjeux, J. Véran, F. Sabatier, First clinical case report of local microinjection of autologous fat and adipose-derived stromal vascular fraction for perianal fistula in Crohn's disease, Stem Cell Res Ther. 9 (2018) 4. https://doi.org/10.1186/s13287-017-0736-6. 
[135] M. Serrero, F. Grimaud, C. Philandrianos, C. Visée, F. Sabatier, J.-C. Grimaud, Long-term Safety and Efficacy of Local Microinjection Combining Autologous Microfat and AdiposeDerived Stromal Vascular Fraction for the Treatment of Refractory Perianal Fistula in Crohn's Disease, Gastroenterology. 156 (2019) 2335-2337.e2. https://doi.org/10.1053/j.gastro.2019.01.032.

[136] C. Zhou, M. Li, Y. Zhang, M. Ni, Y. Wang, D. Xu, Y. Shi, B. Zhang, Y. Chen, Y. Huang, S. Zhang, H. Shi, B. Jiang, Autologous adipose-derived stem cells for the treatment of Crohn's fistula-in-ano: an open-label, controlled trial, Stem Cell Res Ther. 11 (2020) 124. https://doi.org/10.1186/s13287-020-01636-4

[137] A. Dige, H.T. Hougaard, J. Agnholt, B.G. Pedersen, M. Tencerova, M. Kassem, K. Krogh, L. Lundby, Efficacy of Injection of Freshly Collected Autologous Adipose Tissue Into Perianal Fistulas in Patients With Crohn's Disease, Gastroenterology. 156 (2019) 2208-2216.e1. https://doi.org/10.1053/j.gastro.2019.02.005.

[138] S. Norderval, L. Lundby, H. Hougaard, S. Buntzen, S. Weum, L. de Weerd, Efficacy of autologous fat graft injection in the treatment of anovaginal fistulas, Tech Coloproctol. 22 (2018) 45-51. https://doi.org/10.1007/s10151-017-1739-0.

[139] P. Sileri, S. Mastrovito, F. Nicoli, A. Orlandi, M. Shalaby, Autotransplantation of autologous adipose tissue-derived mesenchymal stem cells to treat complex fistula-in-ano - the FLiRT technique - a video vignette, Colorectal Dis. 21 (2019) 247-249. https://doi.org/10.1111/codi.14531.

[140] J. Panés, D. García-Olmo, G.V. Assche, J.F. Colombel, W. Reinisch, D.C. Baumgart, A. Dignass, M. Nachury, M. Ferrante, L. Kazemi-Shirazi, J.C. Grimaud, F. de la Portilla, E. Goldin, M.P. Richard, M.C. Diez, I. Tagarro, A. Leselbaum, S. Danese, J. Panés, D.C. Baumgart, J.F. Colombel, S. Danese, G.V. Assche, W. Reinisch, D. García-Olmo, A. Stift, J. Tschmelitsch, K. Mrak, H. Tilg, I. Kroberger, A. D’Hoore, D.D. Looze, F. Baert, P. Pattyn, P. Zerbib, F. Zerbib, S. Viennot, J.-L. Dupas, P.-C. Orsoni, X. Hebuterne, A. Rahili, M. Allez, Y. Panis, M. Reinshagen, R. Scherer, A. Sturm, W. Kruis, D.-S. Duek, M. Waterman, A. Lahat-Zok, O. Zmora, H. Tulchinsky, Y. Edden, A. Spinelli, V. Annese, I. Angriman, G. Riegler, F. Selvaggi, B. Oldenburg, L. Gilissen, G.V. Montfort, M. Lowenberg, A.W. Bemelman, R. Almenara, M.D.M. Arranz, M. García-Arranz, J.P. Gisbert, R. Palasí, C.T. Samsó, J.M.H. Justiniano, R Rada, M.T. Butrón, D.C. López, A. López-Sanromán, J.H. de Val, A. Solana, F.X.G. Argenté, C. Pastor, H. Guadalajara, Long-term Efficacy and Safety of Stem Cell Therapy (Cx601) for Complex Perianal Fistulas in Patients With Crohn's Disease, Gastroenterology. 154 (2018) 1334-1342.e4. https://doi.org/10.1053/j.gastro.2017.12.020.

[141] R. Meisel, A. Zibert, M. Laryea, U. Göbel, W. Däubener, D. Dilloo, Human bone marrow stromal cells inhibit allogeneic T-cell responses by indoleamine 2,3-dioxygenase-mediated tryptophan degradation, Blood. 103 (2004) 4619-4621. https://doi.org/10.1182/blood-2003-113909.

[142] R. Ciccocioppo, G.C. Cangemi, P. Kruzliak, A. Gallia, E. Betti, C. Badulli, M. Martinetti, M. Cervio, A. Pecci, V. Bozzi, P. Dionigi, L. Visai, A. Gurrado, C. Alvisi, C. Picone, M. Monti, M.E. Bernardo, P. Gobbi, G.R. Corazza, Ex vivo immunosuppressive effects of mesenchymal stem cells on Crohn's disease mucosal T cells are largely dependent on indoleamine 2,3dioxygenase activity and cell-cell contact, Stem Cell Res Ther. 6 (2015) 137. https://doi.org/10.1186/s13287-015-0122-1

[143] M. García-Arranz, U. Gómez-Pinedo, D. Hardisson, D. Herreros, H. Guadalajara, I. GarcíaGómez, J.M. García-Verdugo, D. García-Olmo, Histopathological analysis of human specimens removed from the injection area of expanded adipose-derived stem cells, Histopathology. 56 (2010) 979-982. https://doi.org/10.1111/j.1365-2559.2010.03573.x.

[144] M.C. Barnhoorn, A.G.S. Van Halteren, M. Van Pel, I. Molendijk, A.C. Struijk, P.M. Jansen, H.W. Verspaget, G. Dijkstra, L.E.M. Oosten, A.E. Van der Meulen-de Jong, Lymphoproliferative Disease in the Rectum 4 Years After Local Mesenchymal Stromal Cell 
Therapy for Refractory Perianal Crohn's Fistulas: A Case Report, J Crohns Colitis. 13 (2019) 807-811. https://doi.org/10.1093/ecco-jcc/jjy220.

[145] R. Sanz-Baro, M. García-Arranz, H. Guadalajara, P. de la Quintana, M.D. Herreros, D. García-Olmo, First-in-Human Case Study: Pregnancy in Women With Crohn's Perianal Fistula Treated With Adipose-Derived Stem Cells: A Safety Study, Stem Cells Transl Med. 4 (2015) 598-602. https://doi.org/10.5966/sctm.2014-0255.

[146] R. Ciccocioppo, C. Klersy, D.A. Leffler, R. Rogers, D. Bennett, G.R. Corazza, Systematic review with meta-analysis: Safety and efficacy of local injections of mesenchymal stem cells in perianal fistulas, JGH Open. 3 (2019) 249-260. https://doi.org/10.1002/jgh3.12141.

[147] F. Cheng, Z. Huang, Z. Li, Mesenchymal stem-cell therapy for perianal fistulas in Crohn's disease: a systematic review and meta-analysis, Tech Coloproctol. 23 (2019) 613-623. https://doi.org/10.1007/s10151-019-02024-8.

[148] A.L. Lightner, Z. Wang, A.C. Zubair, E.J. Dozois, A Systematic Review and Meta-analysis of Mesenchymal Stem Cell Injections for the Treatment of Perianal Crohn's Disease: Progress Made and Future Directions, Dis. Colon Rectum. 61 (2018) 629-640. https://doi.org/10.1097/DCR.0000000000001093.

[149] Y. Cao, Q. Su, B. Zhang, F. Shen, S. Li, Efficacy of stem cells therapy for Crohn's fistula: a meta-analysis and systematic review, Stem Cell Res Ther. 12 (2021) 32. https://doi.org/10.1186/s13287-020-02095-7.

[150] J. Yang, X.-X. Liu, H. Fan, Q. Tang, Z.-X. Shou, D.-M. Zuo, Z. Zou, M. Xu, Q.-Y. Chen, Y. Peng, S.-J. Deng, Y.-J. Liu, Extracellular Vesicles Derived from Bone Marrow Mesenchymal Stem Cells Protect against Experimental Colitis via Attenuating Colon Inflammation, Oxidative Stress and Apoptosis, PLoS ONE. 10 (2015) e0140551. https://doi.org/10.1371/journal.pone.0140551.

[151] F. Mao, Y. Wu, X. Tang, J. Kang, B. Zhang, Y. Yan, H. Qian, X. Zhang, W. Xu, Exosomes Derived from Human Umbilical Cord Mesenchymal Stem Cells Relieve Inflammatory Bowel Disease in Mice, Biomed Res Int. 2017 (2017) 5356760. https://doi.org/10.1155/2017/5356760.

[152] M.C. Barnhoorn, L. Plug, E.S.M.M. Jonge, D. Molenkamp, E. Bos, M.J.A. Schoonderwoerd, W.E. Corver, A.E. van der Meulen-de Jong, H.W. Verspaget, L.J. a. C. Hawinkels, Mesenchymal Stromal Cell-Derived Exosomes Contribute to Epithelial Regeneration in Experimental Inflammatory Bowel Disease, Cell Mol Gastroenterol Hepatol. 9 (2020) 715 717.e8. https://doi.org/10.1016/j.jcmgh.2020.01.007.

[153] A. Avivar-Valderas, C. Martín-Martín, C. Ramírez, B. Del Río, R. Menta, P. MancheñoCorvo, M. Ortiz-Virumbrales, Á. Herrero-Méndez, J. Panés, D. García-Olmo, J.L. Castañer, I. Palacios, E. Lombardo, W. Dalemans, O. DelaRosa, Dissecting Allo-Sensitization After Local Administration of Human Allogeneic Adipose Mesenchymal Stem Cells in Perianal Fistulas of Crohn's Disease Patients, Front Immunol. 10 (2019) 1244. https://doi.org/10.3389/fimmu.2019.01244.

[154] D.W. Borowski, T.S. Gill, A.K. Agarwal, P. Bhaskar, Autologous adipose-tissue derived regenerative cells for the treatment of complex cryptoglandular fistula-in-ano: a report of three cases, BMJ Case Rep. 2012 (2012). https://doi.org/10.1136/bcr-2012-006988.

[155] T. Georgiev-Hristov, H. Guadalajara, M.D. Herreros, A.L. Lightner, E.J. Dozois, M. GarcíaArranz, D. García-Olmo, A Step-By-Step Surgical Protocol for the Treatment of Perianal Fistula with Adipose-Derived Mesenchymal Stem Cells, J Gastrointest Surg. 22 (2018) 2003-2012. https://doi.org/10.1007/s11605-018-3895-6.

[156] J.W. Jung, M. Kwon, J.C. Choi, J.W. Shin, I.W. Park, B.W. Choi, J.Y. Kim, Familial Occurrence of Pulmonary Embolism after Intravenous, Adipose Tissue-Derived Stem Cell Therapy, Yonsei Med J. 54 (2013) 1293-1296. https://doi.org/10.3349/ymj.2013.54.5.1293.

[157] M. Brennan, Fibrin glue, Blood Rev. 5 (1991) 240-244. https://doi.org/10.1016/0268960x(91)90015-5. 
[158] S. Shawki, S.D. Wexner, Idiopathic fistula-in-ano, World J. Gastroenterol. 17 (2011) 32773285. https://doi.org/10.3748/wjg.v17.i28.3277.

[159] I. Molendijk, A.E. van der Meulen-de Jong, H.W. Verspaget, R.A. Veenendaal, D.W.

Hommes, B.A. Bonsing, K.C.M.J. Peeters, Standardization of mesenchymal stromal cell therapy for perianal fistulizing Crohn's disease, Eur J Gastroenterol Hepatol. 30 (2018) 1148-1154. https://doi.org/10.1097/MEG.0000000000001208.

[160] D.G. Phinney, M.F. Pittenger, Concise Review: MSC- Derived Exosomes for Cell- Free Therapy, STEM CELLS. 35 (2017) 851-858. https://doi.org/10.1002/stem.2575.

[161] E. Rohde, K. Pachler, M. Gimona, Manufacturing and characterization of extracellular vesicles from umbilical cord-derived mesenchymal stromal cells for clinical testing,

Cytotherapy. 21 (2019) 581-592. https://doi.org/10.1016/j.jcyt.2018.12.006. 